https://helda.helsinki.fi

\title{
Current Status and Future Prospects of C1 Domain Ligands as Drug Candidates
}

\section{Boije af Gennäs, Gustav}

2011

Boije af Gennäs , G , Talman , V , Yli-Kauhaluoma , J , Tuominen , R K \& Ekokoski , E 2011

, ' Current Status and Future Prospects of C1 Domain Ligands as Drug Candidates ',

Current Topics in Medicinal Chemistry, vol. 11, no. 11, pp. 1370-1392 .

http://hdl.handle.net/10138/161200

acceptedVersion

Downloaded from Helda, University of Helsinki institutional repository.

This is an electronic reprint of the original article.

This reprint may differ from the original in pagination and typographic detail.

Please cite the original version. 


\section{Current Status and Future Prospectives of C1 Domain Ligands as Drug Candidates}

\section{Running title: C1 domain ligands in drug development}

Gustav Boije af Gennäs ${ }^{1}$, Virpi Talman ${ }^{2}$, Jari Yli-Kauhaluoma ${ }^{1}$, Raimo K Tuominen ${ }^{2}$ and Elina Ekokoski ${ }^{2 *}$

${ }^{1}$ Division of Pharmaceutical Chemistry, Faculty of Pharmacy, P.O. Box 56 (Viikinkaari 5 E), FI-00014 University of Helsinki, Finland, ${ }^{2}$ Division of Pharmacology and Toxicology, Faculty of Pharmacy, P.O. Box 56 (Viikinkaari 5 E), FI-00014 University of Helsinki, Finland

* Corresponding author: Elina Ekokoski, Division of Pharmacology and Toxicology, Faculty of Pharmacy, P.O.Box 56 (Viikinkaari 5 E), FI-00014 University of Helsinki, Finland. Tel. +358-9-19159461; Fax +358-9-19159471; email elina.ekokoski@helsinki.fi 
Boije af Gennäs G et al. Curr Top Med Chem. 2011; 11(11): 1370-92

The final version of record is available at http://www.eurekaselect.com/88010/article

DOI: $10.2174 / 156802611795589584$

\section{ABSTRACT}

Protein kinase $\mathrm{C}(\mathrm{PKC})$ comprises a family of ten isoforms that play roles in diverse cellular processes such as proliferation, apoptosis and differentiation. PKC isoforms respond to Gprotein coupled receptor- and receptor tyrosine kinase-signaling via binding the second messenger diacylglycerol with $\mathrm{C} 1$ domains. Aberrant signaling through $\mathrm{PKC}$ isoforms and other $\mathrm{C} 1$ domain-containing proteins has been implicated in several pathological disorders. Drug discovery concerning $\mathrm{C} 1$ domains has exploited natural products and rationally designed compounds. Currently, molecules from several classes of $\mathrm{C} 1$ domain-binding compounds are in clinical trials; however, still more have the potential to enter the drug development pipeline. This review gives a summary of the recent developments in $\mathrm{C} 1$ domain-binding compounds.

\section{KEY WORDS}

Protein kinase C; C1 domain; drug discovery; cancer; Alzheimer's disease; bryostatins; ingenol-3-angelate; DAG-lactones 
Boije af Gennäs G et al. Curr Top Med Chem. 2011; 11(11): 1370-92

The final version of record is available at http://www.eurekaselect.com/88010/article

DOI: $10.2174 / 156802611795589584$

\section{INTRODUCTION}

Protein kinase $\mathrm{C}(\mathrm{PKC})$ is a family of at least ten isoenzymes involved in the regulation of cell morphology and various cell functions such as proliferation, metabolism and apoptosis. PKCs mediate signals that originate from the activation of G-protein-coupled receptors and receptor tyrosine kinases and lead to phospholipase $\mathrm{C}$ activation and the subsequent hydrolysis of cell membrane phospholipids [1]. PKC isoforms are classified into three subgroups according to their structure and activation mechanisms. Classical/conventional PKCs (cPKCs: $\alpha, \beta \mathrm{I}, \beta \mathrm{II}$ and $\gamma$ ) require calcium and diacylglycerol (DAG) for activation and novel PKCs (nPKCs: $\delta, \varepsilon, \eta$ and $\theta$ ) are activated by DAG. Atypical PKCs (aPKCs: $\zeta$ and $1 / \lambda$ ) require neither calcium nor DAG (Figure 1) [2,3]. The activation of PKC is controlled by the regulatory region in the amino terminal part of the enzyme, which, in the case of classical and novel isoforms, contains the $\mathrm{C} 1$ domain. The $\mathrm{C} 1$ domain of cPKCs and $\mathrm{nPKCs}$ is a duplicated cysteine-rich sequence (containing $\mathrm{C} 1 \mathrm{a}$ and $\mathrm{C} 1 \mathrm{~b}$ subdomains) that binds endogenous DAG and tumor-promoting phorbol esters. Binding of either of these ligands leads to the translocation of the enzyme to cell membranes and a subsequent conformational change unveiling the catalytic site and leading to enzyme activation. The $\mathrm{C} 1$ domain of atypical PKCs is unresponsive to DAG and phorbol esters.

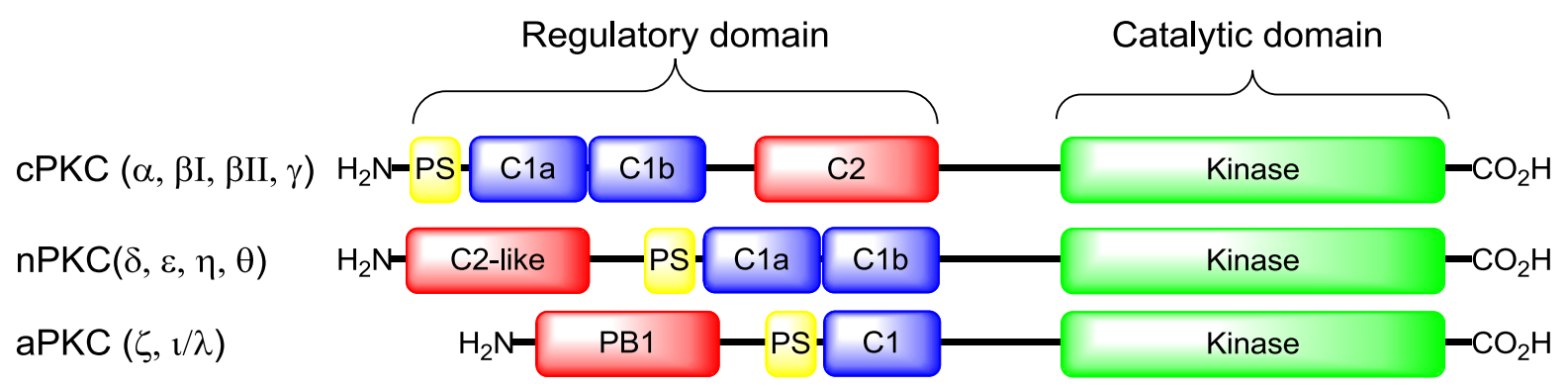

Figure 1. Structures of protein kinase $\mathrm{C}$ isoforms. $\mathrm{PS}=$ pseudosubstrate, $\mathrm{PB} 1=$ phox-Bem1. 
Boije af Gennäs G et al. Curr Top Med Chem. 2011; 11(11): 1370-92

The final version of record is available at http://www.eurekaselect.com/88010/article

DOI: $10.2174 / 156802611795589584$

There is a large body of evidence supporting the potential of PKC isoforms as therapeutic targets in cancer $[4,5]$, immunological diseases [6, 7], cardiovascular diseases [8-10] and neurological diseases [11], especially Alzheimer's disease (AD) [12-14]. However, proper target validation is possible only when potent and specific ligands are available. The conventional route of producing kinase inhibitors by targeting the ATP binding site has not been successful with PKC because most of the inhibitors reported in the literature are poorly selective. Some degree of selectivity has been achieved with enzastaurin (LY317615) and ruboxistaurin (LY333531), which have been reported to be selective for PKC $\beta$ at nanomolar concentrations, although they also inhibit other kinases $[15,16]$. These compounds have been studied in phase III clinical trials for the treatment of cancer and diabetic complications, respectively, but their efficacy has not been proven yet. Problems with achieving selectivity are not surprising because there are potentially more than 500 kinases [17] with relatively homologous ATP-binding sites. Moreover, the 3D crystal structures of only three PKC catalytic domains ( $\beta, \theta$ and $\imath$ ) have been resolved. Therefore, targeting the regulatory part of PKC could provide a way to develop PKC selective compounds.

The $\mathrm{C} 1$ domain was first identified in $\mathrm{PKC}$, but later six other protein families with a DAG and phorbol ester-responsive $\mathrm{C} 1$ domain were identified: the protein kinase $\mathrm{D}$ (PKD), the chimaerins, the guanyl nucleotide-releasing proteins RasGRPs, the Unc-13 scaffolding proteins, the myotonic dystrophy kinase-related Cdc42-binding kinases (MRCKs), and the DAG kinase (DGK) isoforms $\beta$ and $\gamma$. PKD, DGK and the chimaerins are involved in the regulation of cell growth, proliferation and motility, among other things, and may therefore be implicated in the pathology of cancer [18-20]. RasGRPs and DGK regulate immune cell signaling [20, 21], whereas Munc13 isoforms (the mammalian homologs of the yeast Unc-13) are involved in exocytotic processes [22]. MRCK is known to control cytoskeletal 
Boije af Gennäs G et al. Curr Top Med Chem. 2011; 11(11): 1370-92

The final version of record is available at http://www.eurekaselect.com/88010/article

DOI: $10.2174 / 156802611795589584$

reorganization [23] - a process that is also regulated by PKCs, DGKs and the chimaerins [24]. Thus, $\mathrm{PKC}$ is not the only potential drug target among $\mathrm{C} 1$ domain-containing proteins.

At present, the disease models (both in vitro and in vivo) in which the effects of $\mathrm{C} 1$ domain ligands have been characterized are mainly based on the proposed role of PKC in the pathophysiology of cancer and AD. In cancer, the differential effects of PKC isoforms on cell proliferation and apoptosis form the basis for targeting PKC. In the central nervous system, $\mathrm{PKC}$ regulates processes linked to memory and learning [12]. In $\mathrm{AD}$, certain $\mathrm{PKC}$ isoforms promote the processing of amyloid precursor protein (APP) via the non-pathological pathway, thereby causing a relative decrease in pathological A $\beta$ levels [12]. In addition, neuroprotection in stroke [10], cardiac failure and cardioprotection during ischemia [9] as well as diabetic complications [15], autoimmune diseases [7] and HIV-1 infection [25] are relevant in considering possible indications for PKC or $\mathrm{C} 1$ domain-targeted treatment.

The use of the $\mathrm{C} 1$ domain as a drug target has aroused interest in several research groups [26]. Compared to the ATP binding site, the $\mathrm{C} 1$ domain possesses several advantages as a drug target. First, the number of $\mathrm{C} 1$ domain-containing proteins is relatively small. Second, targeting the $\mathrm{C} 1$ domain provides the possibility of developing PKC activators. Third, the PKC regulatory domain may have biological functions independent of catalytic activity [2729], and the $\mathrm{C} 1$ domain can act as a protein-interaction module [30]. Fourth, targeting the $\mathrm{C} 1$ domain provides a way to target other $\mathrm{C} 1$ domain-containing proteins in addition to $\mathrm{PKC}$, thereby enhancing the effect on the signaling pathways that those proteins regulate at different levels. Several compounds targeted to the $\mathrm{C} 1$ domain have entered clinical trials, providing further validation for the $\mathrm{C} 1$ domain as a drug target.

Most of the $\mathrm{C} 1$ domain ligands currently known are either derived straight from nature or are derivatives or analogues of naturally occurring compounds. The chemistry of the naturally derived $\mathrm{C} 1$ domain ligands (including phorbol esters, bryostatins, teleocidins and 
Boije af Gennäs G et al. Curr Top Med Chem. 2011; 11(11): 1370-92

The final version of record is available at http://www.eurekaselect.com/88010/article

DOI: $10.2174 / 156802611795589584$

aplysiatoxins) is complex and their commercial production and chemical modification is thus generally unfeasible. Therefore, two main strategies have been applied to develop novel C1 domain ligands by (1) simplifying the chemical structure of the natural ligands (bryostatin analogues, benzolactams) or by (2) using DAG as starting point and working towards more constrained and complex structures (DAG-lactones). Additionally, C1 domain ligands have been discovered by screening campaigns and structure-based design; 5(Hydroxymethyl)isophthalates, $N$-benzyladriamycin-14-valerate (AD 198), calphostin C and resveratrol are examples of these ligands. This review focuses on recent advances in the development of $\mathrm{C} 1$ domain-targeted compounds and evaluates their potential in drug development.

\section{THE CRYSTAL STRUCTURE OF THE PKCס C1B DOMAIN}

Rational drug design for targeting the $\mathrm{C} 1$ domain containing proteins has been hampered by the lack of solved crystal structures. Consequently, pharmacophores obtained from natural products have been used in the development of analogues targeted to the $\mathrm{C} 1$ domain. To date, the crystal structure of the $\mathrm{C} 1 \mathrm{~b}$ domain of $\mathrm{PKC} \delta$ complexed with phorbol 13-O-acetate $(\mathbf{1}$, crystallized at 2.2 A resolution; PDB ID: 1PTR, Figure 2) is the only available 3D structure of a PKC $\mathrm{C} 1$ domain [31]. The crystal structure reveals a domain whose "top" third is hydrophobic and that contains a deep, narrow and polar groove that binds diacylglycerol (DAG, 2) and phorbol esters (3). The "central" part of the domain is hydrophilic and the "bottom" third of the domain contains negatively charged amino acids. The $\mathrm{C} 1$ domain bound to DAG or phorbol ester is thought to be partly buried in the membrane bilayer [32] because the ligands can act as caps on the top part of the domain to produce a continuous hydrophobic surface. To further stabilize the penetration of the $\mathrm{C} 1$ domain into the bilayer, the positively 
Boije af Gennäs G et al. Curr Top Med Chem. 2011; 11(11): 1370-92

The final version of record is available at http://www.eurekaselect.com/88010/article

DOI: $10.2174 / 156802611795589584$

charged amino acids in the central part of the domain could interact with anionic membrane phospholipids and the negatively charged amino acids in the bottom of the domain could face the cytoplasm.

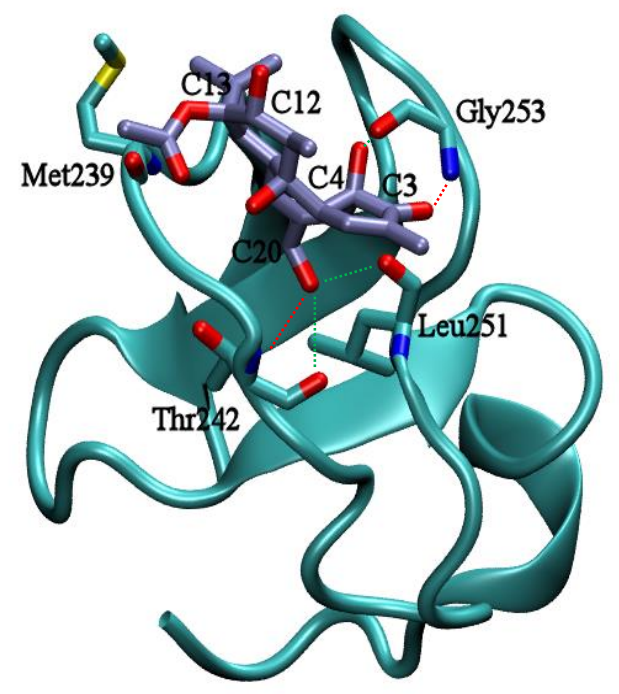

Figure 2. The crystal structure of the $\mathrm{PKC} \delta \mathrm{C} 1 \mathrm{~b}$ domain complexed with phorbol 13-Oacetate (1). The pivotal polar functional groups of the phorbol ester involved in $\mathrm{C} 1$ domain recognition include the hydroxyl groups in the carbon atoms C4 and C20 and the carbonyl group on C3 [31]. The carbonyls of Gly253, Leu251 and Thr242 are hydrogen-bond acceptors (green dotted lines), and the amide protons of Gly253 and Thr242 are hydrogenbond donors (red dotted lines). The figure was created using VMD (v.1.8.6., University of Illinois, USA).

The binding site of DAG/ phorbol esters in the regulatory domain forms a deep polar groove between two $\beta$-sheets (Figure 2). The carbonyls of Leu251 and Thr242 at the bottom of the groove act as hydrogen-bond acceptors for the hydroxyl of the C20 of phorbol esters. In addition, the amide hydrogen of Thr242 can act as a hydrogen-bond donor for the hydroxyl of the $\mathrm{C} 20$ of phorbol esters. Furthermore, the carbonyl and the amide proton of Gly253 interact with the $\mathrm{C} 4$ hydroxyl and the $\mathrm{C} 3$ carbonyl of phorbol 13-O-acetate, respectively. The same interactions to Leu251 and Thr242 can be found with the C3 hydroxyl (Figure 3). In addition, the carbonyl group of the acyl moiety of DAG at $\mathrm{C} 1$ has the same interaction with the protein 
Boije af Gennäs G et al. Curr Top Med Chem. 2011; 11(11): 1370-92

The final version of record is available at http://www.eurekaselect.com/88010/article

DOI: $10.2174 / 156802611795589584$

as the C3 carbonyl of phorbol esters. In phorbol esters, the C13 carbonyl group (e.g., compound 4) is essential for high-affinity binding while the C12 carbonyl group is not (e.g., compound 5) [33-35]. Although the crystal structure does not reveal any interactions of the C13 carbonyl to the protein, it is speculated that this carbonyl is bridged via a water molecule to the backbone carbonyl of Met239, to the bilayer and/ or to the C9 hydroxyl [36, 37]. Furthermore, no interaction between the C9 hydroxyl and the protein can be observed in the crystal structure, but it has been shown that the C9 hydroxyl is involved in interactions with the bilayer. To accomplish PKC activity, the absolute configuration of the hydroxyl-bearing carbon atom $\mathrm{C} 4$ in phorbol esters has to be $R$, the respective $S$-configuration (e.g., compound 6) provides an inactive compound [38]. However, the C4 hydroxyl is not essential to provide high binding affinity to $\mathrm{PKC}[39]$.

In addition to the crystal structure of the $\mathrm{PKC} \delta \mathrm{C} 1 \mathrm{~b}$ domain, Canagarajah et al. reported the crystal structure of the uncomplexed and intact $\beta 2$-chimaerin at $3.2 \AA$ resolution (PDB ID: 1XA6) [40]. The $\mathrm{C} 1$ domain of $\beta 2$-chimaerin was closely superimposable on the $\mathrm{C} 1 \mathrm{~b}$ domain of $\mathrm{PKC} \delta$. However, in the crystal structure of $\beta 2$-chimaerin, a part of the $\mathrm{N}$-terminus (residues 27-34) forms a helix that covers the binding groove of the $\mathrm{C} 1$ domain. In addition, Gln32 forms hydrogen bonds with Gly235 in the "top" of the binding groove (Gly235 corresponds to Gly253 in the $\mathrm{PKC} \delta \mathrm{C} 1 \mathrm{~b}$ domain, Figure 2). 


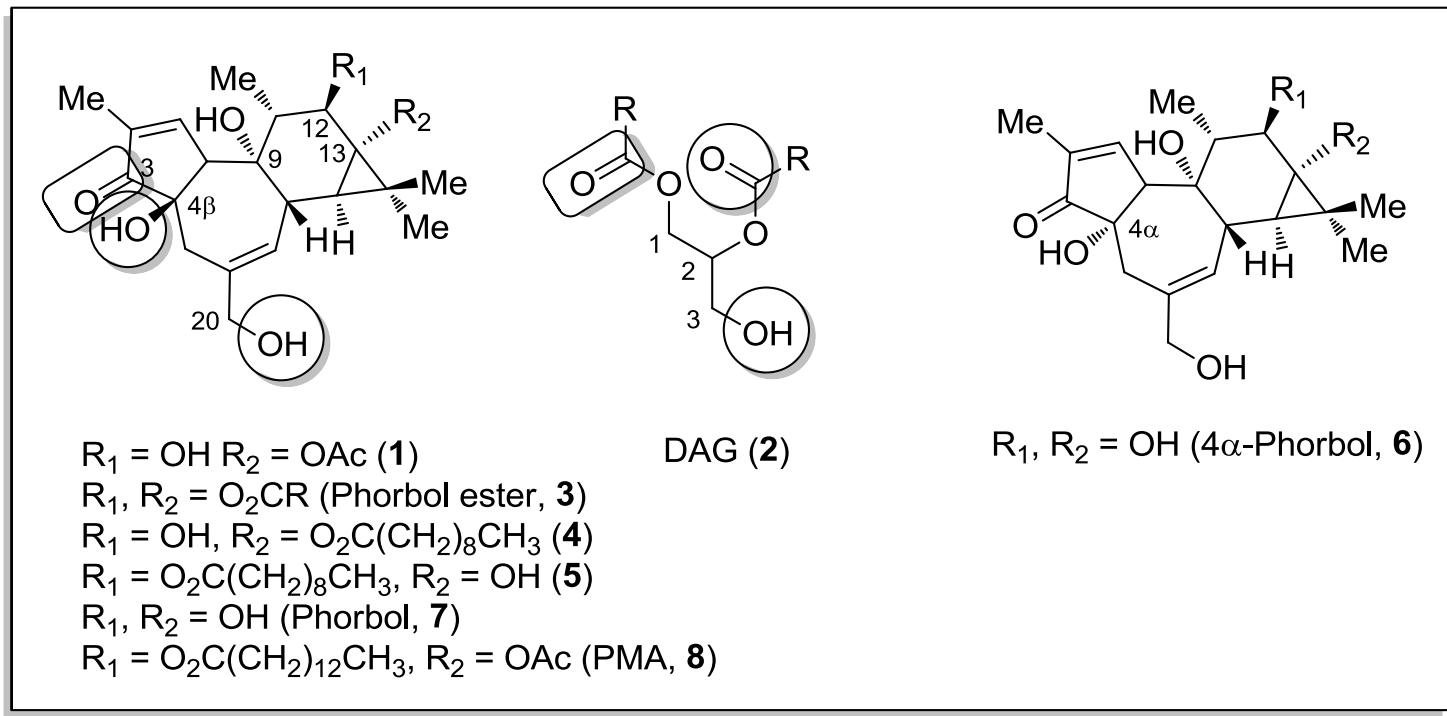

Figure 3. Structures of phorbols (1 and 3-8) and DAG (2). Functional groups that interact with the $\mathrm{C} 1$ domain are highlighted.

\section{BRYOSTATIN 1 AND ITS SYNTHETIC ANALOGUES}

The highly oxygenated macrocyclic lactones bryostatins were originally isolated from the marine bryozoan Bugula neritina [41]; however, the symbiont bacteria might be the actual sources of the compounds [42]. There are at least 20 naturally occurring bryostatins, with bryostatin 1 (9, Figure 4$)$ being the prototype that has been extensively examined. Bryostatin 1 shows very high affinity towards PKC and exhibits unique biological effects when compared to phorbol esters. In general, bryostatin 1 has been reported to act as an antineoplastic agent, to induce differentiation in hematopoietic cells, to activate effector cells of the immune system, to reverse neuronal damage caused by stroke and to rescue long-term memory after ischemia. It has proceeded to clinical trials as a potential treatment for different cancers and AD. In addition, several synthetic analogues of bryostatin 1 have been prepared, and structure-activity studies have been performed. 


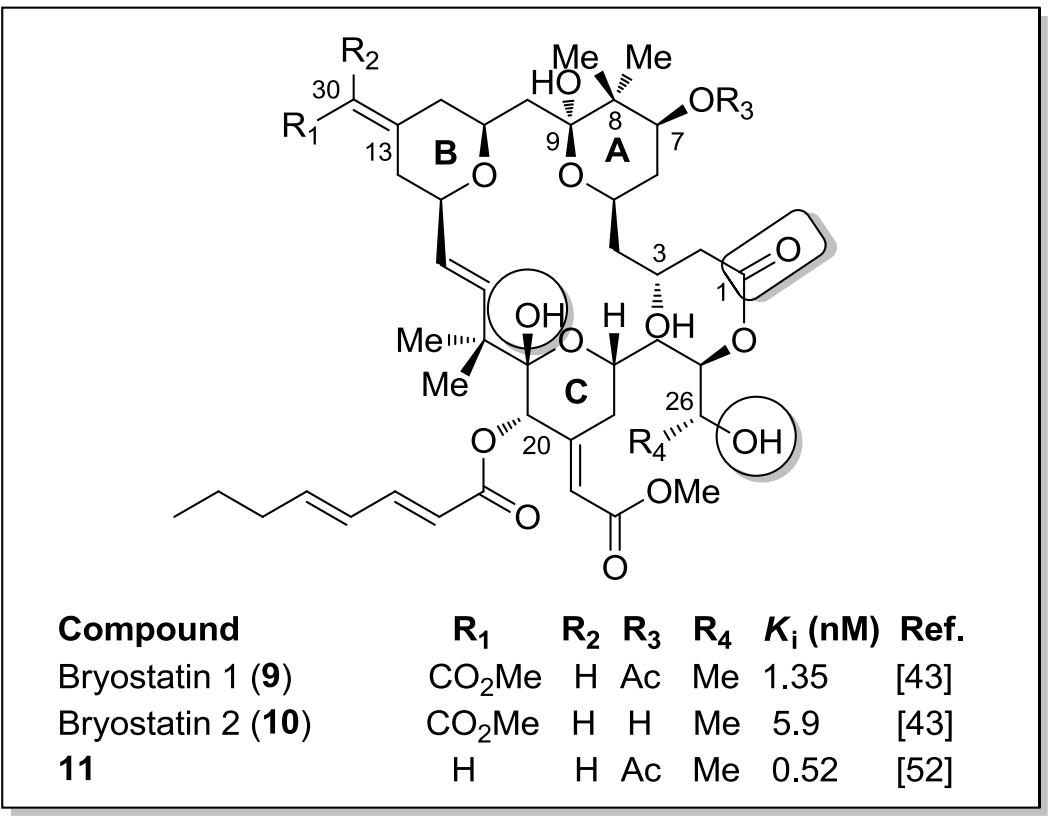

Figure 4. Structures of bryostatins (9-11). Functional groups that interact with the $\mathrm{C} 1$ domain are highlighted.

\section{Structure-activity studies}

Bryostatin 1 binds to PKC $\alpha$ with a $K_{\mathrm{i}}$ of $1.35 \mathrm{nM}$ [43]. The bryostatins are highly complex macrolactones containing several stereocenters, and their total syntheses require over 40 linear steps [44-46]. Therefore, the Wender group developed a synthesis route for simplified derivatives of bryostatin 1 with a significantly reduced number of reaction steps $[47,48]$. Removal of the methyl substituent at C26 of compound $\mathbf{1 3}\left(K_{\mathrm{i}}=3.4 \mathrm{nM}\right.$ of PKC) [49] gave compound 12, which showed higher affinity $\left(K_{\mathrm{i}}=0.25 \mathrm{nM}\right.$ of PKC) [43], as predicted by the pharmacophore of phorbol esters (3) (Table 1). Interestingly, the addition of an acetoxy substituent to $\mathrm{C} 7$, similarly to bryostatin 1 , reduced the $K_{\mathrm{i}}$ value to $13 \mathrm{nM}$ (compound 14), and the addition of a hydroxyl group to $\mathrm{C} 7$ (analogues 15 and 16) reduced the binding affinity even further by three to four orders of magnitude. On the other hand, bryostatin $2(\mathbf{1 0})$, with a hydroxyl group at $\mathrm{C} 7$, shows only a slight reduction in binding affinity compared to bryostatin 1 [43]. It has been speculated that these differences in binding affinities are due to the C8 gem-dimethyl groups, which are able to shield a polar C7 substituent. This hypothesis 
Boije af Gennäs G et al. Curr Top Med Chem. 2011; 11(11): 1370-92

The final version of record is available at http://www.eurekaselect.com/88010/article

DOI: $10.2174 / 156802611795589584$

was proven correct by the corresponding pivaloyloxy (analogue 17) and methylene (analogue 18) derivatives, which showed better binding affinities ( $K_{\mathrm{i}}$ of 6.6 and $5.3 \mathrm{nM}$, respectively) compared to compound 14. Furthermore, the Blumberg group showed that the removal of the methyl and hydroxyl groups in ring A of bryostatin 1 gave compounds that retained excellent binding to $\mathrm{PKC} \alpha(0.7-3.0 \mathrm{nM}$, compounds 21-24) but that evoked phorbol-like tumor promoting responses [50, 51]. Alternatively, compound 11, which has the same C7-C9 substituents as bryostatin 1 and lacks only the C30 methoxy carbonyl group, showed a $K_{\mathrm{i}}$ value of $0.52 \mathrm{nM}$ for PKC $\alpha$ but is also a functional antagonist of PMA (8) [52]. In contrast to these findings, derivatives $\mathbf{1 9 - 2 0}$ and $\mathbf{2 5 - 2 7}$ synthesized by the Wender group, lacking all the A-ring substituents but having the $\mathrm{C} 13$ substituted, showed high affinities to $\mathrm{PKC}\left(K_{\mathrm{i}}=0.67\right.$ $2.5 \mathrm{nM}$ ), and compounds 25-27 inhibited the growth of K562 and MV411 leukemia cells [53, 54]. Furthermore, different esters at $\mathrm{C} 20$ do not seem to affect binding $[52,55]$, and the $\mathrm{C} 3$ hydroxyl group is pivotal for high binding affinity [49]. Taken together, the SAR studies suggest that the C26 methyl of bryostatin 1 is not essential for its PKC binding activity and that the A- and B-rings can be modified to achieve anti-tumor promoting analogues of bryostatin.

Table 1. Structures and binding affinities of bryostatin derivatives (12-27). Functional groups that interact with the $\mathrm{C} 1$ domain are highlighted. 


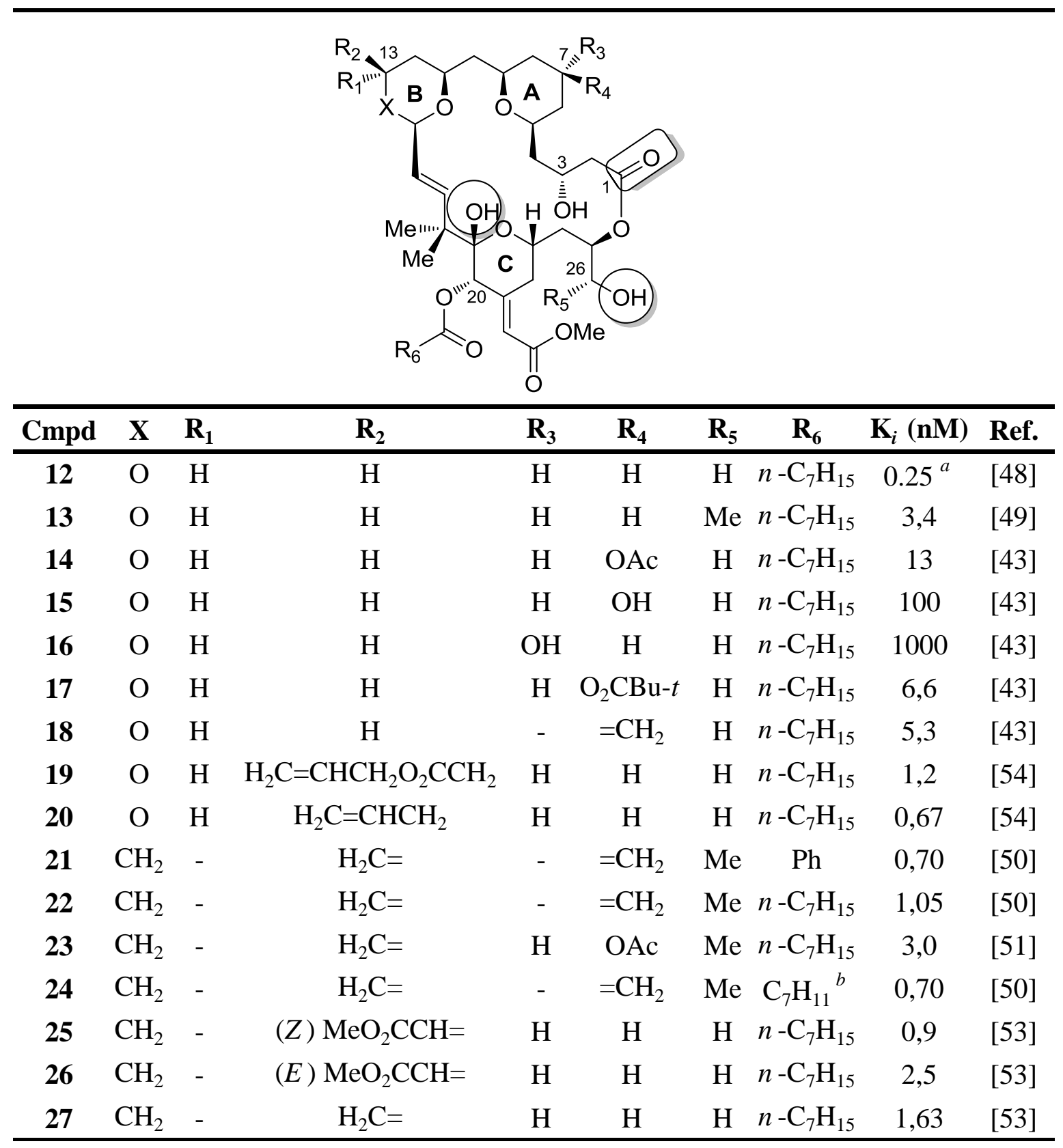

${ }^{a}$ Wender et al. also reported a $K_{i}$-value of $3.1 \mathrm{nM}$ for the same derivative [53]. ${ }^{b} \mathrm{C}_{7} \mathrm{H}_{11}=$ (1E,3E)-hepta-1,3-dienyl.

\section{Interaction with $\mathrm{PKC}$ and other $\mathrm{C} 1$-containing proteins}

Bryostatin 1 binds to $\mathrm{PKC}$ with high affinity but without showing considerable isoform specificity in binding or activation [56]. It competes for binding with DAG and phorbol esters, suggesting that they share the same binding site; however, some of the biological effects caused by these agents differ. In general, PMA is a tumor promoter, while bryostatin 1 
Boije af Gennäs G et al. Curr Top Med Chem. 2011; 11(11): 1370-92

The final version of record is available at http://www.eurekaselect.com/88010/article

DOI: $10.2174 / 156802611795589584$

has shown antiproliferative effects. Furthermore, bryostatin 1 acts as a partial functional antagonist, often suppressing or reversing the effects induced by PMA [57-59]. The mechanism behind the functional differences has been an area of intense investigation, but no single mechanism has been revealed. Antagonism, at least for leukemia cell differentiation, is non-competitive [57].

At the cellular level, bryostatin 1 shows differential effects on PKC isoform translocation and down-regulation compared to PMA, which might explain some of the functional differences [60-64]. Bryostatin 1 depends on both the $\mathrm{C} 1 \mathrm{a}$ and $\mathrm{C} 1 \mathrm{~b}$ domains for the induction of PKC translocation, whereas PMA and other tumor promoters mainly depend on the $\mathrm{C} 1 \mathrm{~b}$ domain, a pattern that was proposed to correspond with tumor-promoting activity [65]. Additionally, the bryostatin 1-induced translocation is slower and the localization of the PKC isoforms is different compared to PMA. Bryostatin 1 has been shown to induce more rapid down-regulation of PKC $\alpha$ and PKC $\beta$ compared to PMA [66, 67]. Furthermore, PKC $\delta$ is resistant to bryostatin 1-induced down-regulation at high concentrations, but not at low concentrations [60]. The C1a domain and the catalytic domain might be involved in protection from down-regulation $[61,62]$. Because PMA does not protect PKC from downregulation, unique structural aspects of bryostatin 1 are likely to be involved.

Specific to bryostatin 1 are its biphasic concentration-dependent effects in many biological responses, such as enhancing the proliferation and cytokine secretion of human mononuclear cells [68], inducing c-Jun protein in NIH 3 T3 cells [60], sensitizing HeLa cells to cisplatininduced cell death [69], inducting the proliferation of HOP-02 cells [63], and activating PKD [70]. The underlying mechanism(s) is not clear but could involve differential activation of distinct PKC isoforms [63, 69]. Furthermore, many of the cellular effects caused by bryostatin 1 are thought to depend on binding to PKC isoenzymes; however, activations of 
Boije af Gennäs G et al. Curr Top Med Chem. 2011; 11(11): 1370-92

The final version of record is available at http://www.eurekaselect.com/88010/article

DOI: $10.2174 / 156802611795589584$

other $\mathrm{C} 1$ domain containing proteins such as PKD [70, 71], RasGRPs $[64,72,73]$, and $\beta$ chimaerin [74] have been reported.

\section{Antineoplastic effects}

Bryostatin 1 and several of its synthetic analogues have shown antineoplastic effects or have induced differentiation in several cancer cell lines $[43,48,50-53,75,76]$, in primary cancer cells [77], and in in vivo tumors [78]. However, stimulation of proliferation or antiapoptotic effects has also been reported $[64,79]$. Some of the antineoplastic effects of bryostatin 1 or its analogues occur via PKC isoforms, but some are PKC-independent [64, 71, 80, 81]. Bryostatin 1 has been shown to circumvent resistance to drug-induced apoptosis and to potentiate the effects of other oncolytic agents such as imatinib [82], vincristine [83], and paclitaxel [84].

\section{Immunomodulatory effects}

Bryostatin 1 is a potent activator and modulator of host immune effector cells, which may indirectly cause tumor cell death. Bryostatin 1 can enhance the proliferation and activation of human $\mathrm{T}$ and $\mathrm{B}$ cells $[85,86]$, induce the expression of cytokine receptors [86], enhance the release of cytokines [85, 87], and enhance the immunogenicity of chronic lymphocytic leukemia (CLL) cells [88].

\section{Clinical trials}

Because of the remarkable antineoplastic effects observed in in vitro studies and in preclinical animal experiments, the safety and efficacy of bryostatin 1 have been examined in several clinical trials for the treatment of different cancers either as a single agent or in combination with other established anticancer agents. However, as a single agent, bryostatin 
Boije af Gennäs G et al. Curr Top Med Chem. 2011; 11(11): 1370-92

The final version of record is available at http://www.eurekaselect.com/88010/article

DOI: $10.2174 / 156802611795589584$

1 has not shown efficacy in phase I and II trials for treatment of cancers such as melanoma, renal, colorectal, non-Hodgkin lymphoma, soft tissue sarcoma and head and neck cancers (reviewed in $[89,90])$. Therefore, there are clinical trials focused on using bryostatin 1 in combination with other established antitumor drugs. Most of the combination studies have, however, been disappointing, and bryostatin 1 has shown moderate efficacy in only a few trials (Table 2, [91-98]). In addition, myalgia is a major adverse effect that has limited the use of bryostatin 1 at doses higher than $40-50 \mu \mathrm{g} / \mathrm{m}^{2}$. Despite the disappointing results of bryostatin 1 , researchers are hoping to obtain better results and reduced toxicity with new bryostatin analogues [92].

Table 2. Clinical trials of bryostatin 1 in combination with antitumor agents.

\begin{tabular}{|c|c|c|c|c|}
\hline $\begin{array}{l}\text { Bryostatin } \\
\text { with } \\
\end{array}$ & Phase & Cancer & Result & Ref. \\
\hline Cisplatin & I & $\begin{array}{l}\text { Non-hematologic } \\
\text { tumors }\end{array}$ & PR in 4 out of 53 patiens ${ }^{a}$ & [91] \\
\hline Gemcitabine & I & $\begin{array}{l}\text { Non-hematologic } \\
\text { malignancies }\end{array}$ & $\begin{array}{l}\text { PR in } 2 \text { out of } 36 \text { patients, } \\
8 \text { had stable disease }\end{array}$ & [96] \\
\hline Fludarabine & I & $\begin{array}{l}\text { CLL and indolent } \\
\text { lymphoma }^{b}\end{array}$ & $\begin{array}{l}\text { CR in } 4 \text { out of } 59 \text { patients, } \\
20 \text { had partial remission }{ }^{c}\end{array}$ & [95] \\
\hline Interleukin-2 & II & $\begin{array}{l}\text { Advanced kidney } \\
\text { cancer }\end{array}$ & $\begin{array}{l}\mathrm{PR} \text { in } 1 \text { out of } 33 \text { patients, } \\
1 \text { stable disease }\end{array}$ & [97] \\
\hline \multirow[t]{3}{*}{ Paclitaxel } & II & $\begin{array}{l}\text { Gastric and } \\
\text { gastroesophageal } \\
\text { cancer }\end{array}$ & PR in 10 out of 35 patients & [98] \\
\hline & & $\begin{array}{l}\text { Advanced } \\
\text { esophageal } \\
\text { cancer }\end{array}$ & PR in 6 out of 22 patients & [94] \\
\hline & & $\begin{array}{l}\text { Advanced } \\
\text { pancreatic cancer }\end{array}$ & Inactive & [93] \\
\hline Vincristine & II & $\begin{array}{l}\text { Non-Hodgkin } \\
\text { lymphoma }\end{array}$ & $\begin{array}{l}\mathrm{CR} \text { in } 2 \text { and } \mathrm{PR} \text { in } 2 \text { out of } \\
14 \text { patiens }\end{array}$ & [92] \\
\hline
\end{tabular}

${ }^{a} \mathrm{PR}=$ partial response $;{ }^{b} \mathrm{CLL}=$ chronic lymphocytic leukemia; ${ }^{c} \mathrm{CR}=$ complete response. 


\section{Effects on central nervous system}

A new field of investigations of bryostatin 1 and its analogues concerns their effects on the central nervous system. Bryostatin 1 and its analogue 12 [48] have been shown to enhance the secretion of nontoxic soluble $\operatorname{APP} \alpha(\mathrm{sAPP} \alpha)$ in fibroblasts from AD patients [99], and bryostatin 1 has been shown to reduce the toxic $A \beta_{40}$ and $A \beta_{42}$ peptides in the brains of transgenic mice and to improve behavioral outcomes in an open field test [100]. Due to these very promising results, bryostatin 1 is now about to enter clinical trials to test its efficacy in AD patients [101].

PKC is also implicated in stabilizing the mRNAs of proteins that might be important in the processes of memory and learning [102]. The stabilization is evoked via RNA-binding proteins (RBPs), and some of the most important RBPs are neuronal Embryonic Lethal Abnormal Vision (nELAV)-proteins. These proteins bind to the adenine and uridine richmotifs of the 3'UTR-region of their target mRNA and can affect mRNA splicing, nuclear transport, stability and translation [102]. The nELAV proteins have been shown to be upregulated by bryostatin 1 in human SH-SY5Y neuroblastoma cells and in rat brain [103]. Through the phosphorylation and up-regulation of nELAV proteins, PKC could positively influence the expression of genes important in neurogenesis, memory formation and, possibly, neuroregeneration [102].

Global cerebral ischemia selectively injures the pyramidal neurons in the dorsal hippocampal CA1 area, causing dramatic and long-lasting impairment of spatial learning and memory $[104,105]$. In an animal model of experimental global ischemia, chronic bryostatin 1 administered for 5 weeks, with the first dose given 24 hours after the induced injury, restored the performance of the rats in memory and learning tasks [104]. Bryostatin 1 enhances neurotrophic activity and neuronal survival, prevents synaptic loss and induces 
synaptogenesis after ischemia. These effects are remarkable because current thrombolytic therapy cannot repair the damaged brain tissue and must be administered within 3 hours of the stroke. The action of bryostatin 1 after ischemia is also long lasting [105]. Rats tested 4 months after the administration of the last bryostatin 1 dose performed as well as the control group in tests of spatial learning and memory. Furthermore, bryostatin 1 rescues even previously learned experience.

\section{INGENOL DERIVATIVES}

The sap of the plant Euphorbia peplus has been used as a traditional remedy to treat skinrelated diseases such as warts, corns and skin cancers as well as asthma and migraine [106, 107]. Three major families of macrocyclic diterpenes extracted from E. peplus, the ingenane, the pepluane and the jatrophane families [108] have been identified as the source of agents having cytotoxic, proinflammatory and cell-differentiating activity. Ingenol-3-angelate (PEP005, ingenol mebutate, 28) from the ingenane family has been extensively studied and is considered a potential agent for the treatment of skin tumors [107].

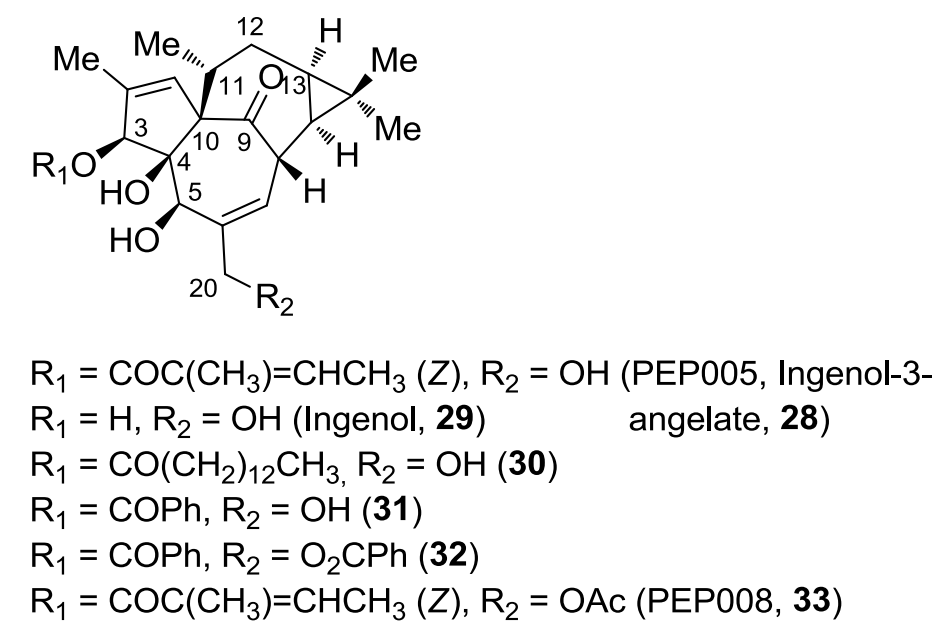

Figure 5. Structures of ingenols (28-33). 


\section{Structure-activity studies}

Even though they are structurally related to phorbol (7), ingenols (28-33) contain some considerable differences within their structures (Figure 5). When compared with the sevenmembered ring of the phorbols, the ingenols have an additional hydroxyl group at $\mathrm{C} 5$, and the C9 hydroxyl of the phorbols is in an oxidation state of a carbonyl. Additionally, the sixmembered ring of the phorbols corresponds to the new seven-membered ring in the ingenol structure. Furthermore, the ingenols have no ester groups at $\mathrm{C} 12$ or $\mathrm{C} 13$, and the $\mathrm{C} 3$ carbonyl found in phorbols is replaced with a hydroxyl group in ingenols. These differences in the structures of the corresponding ingenols make them more hydrophilic than the phorbol esters; for example, the clog $P$ values of ingenol-3-angelate and PMA (8) are 3.89 and 6.65, respectively [109]. The corresponding tetradecanoate (30) [110] and benzoate (31) [111] derivatives have also been studied.

\section{Interaction with PKC}

Ingenol-3-angelate binds to PKC with subnanomolar affinity that shows no selectivity between different $\mathrm{PKC}$ isoforms. However, it activates $\mathrm{PKC} \delta$ more potently than $\mathrm{PKC} \alpha$ in vitro [109]. When compared to PMA, ingenol-3-angelate is less potent in stabilizing the interaction of the PKC $\delta \mathrm{C} 1 \mathrm{~b}$ domain with lipid membranes. The difference in the membrane interaction is thought to correlate with the partial agonism of ingenol-3-angelate in inducing PKC $\alpha$ activation and with the partial antagonism of PKC activation by PMA and 1,2dioctanoyl-sn-glycerol [109]. Ingenol-3-angelate induces a distinct pattern of translocation of $\mathrm{PKC} \delta$ when compared to PMA, with ingenol-3-angelate inducing translocation initially to the nuclear and perinuclear membrane, and PMA inducing translocation to the plasma membrane 
Boije af Gennäs G et al. Curr Top Med Chem. 2011; 11(11): 1370-92

The final version of record is available at http://www.eurekaselect.com/88010/article

DOI: $10.2174 / 156802611795589584$

$[109,112,113]$. The differences in membrane interaction and translocation probably mirror the different lipophilicity between the two agents [109].

\section{Effects on cell proliferation}

In general, ingenol derivatives are considered antineoplastic agents, although cocarcinogenic or anti-apoptotic activity has also been reported [114-117]. Ingenol-3-angelate has been shown to inhibit the proliferation of different cancer cell lines [109, 116, 118-120] as well as primary acute myeloid leukemia (AML) cells $[112,121]$. In contrast, normal primary human neonatal fibroblasts [122] and normal CD34+ cord blood myeloblasts were resistant to permanent growth arrest and apoptosis, respectively [112].

In myeloid leukemia cell lines and in primary AML blasts, ingenol-3-angelate induced apoptosis at low nanomolar concentrations $(<20 \mathrm{nM})$, apparently via the activation of PKC $\delta$ [112]. Normal CD34+ myeloblasts did not undergo apoptosis but were induced to differentiate with higher concentrations of ingenol-3-angelate $(20 \mathrm{nM}-2 \mu \mathrm{M})$. The compound also induced cell differentiation in some leukemia cell lines, as assessed by the increased expression of CD11b protein [112], as well as in primary AML cells, where the expression of leukocyte markers CD11b and CD14 increased and the expression of stem cell marker CD117 decreased [123]. Of the other ingenol ester derivatives, ingenol-3,20-dibenzoate (32) and its analogues induced apoptosis in Jurkat cells via a PKC-independent pathway [114]. The PKC-activating pathway and the apoptosis pathway seemed to be separate, and only those derivatives bearing a benzoate at C20 could induce apoptosis. In addition, a free hydroxyl at C5 was critical for PKC activation.

Permanent growth arrest, called senescence, was reported as the mechanism of cytostatic effect induced by low doses $(0.1-1 \mu \mathrm{g} / \mathrm{ml})$ of ingenol-3-angelate in certain melanoma cell lines [122] and of 20-O-acetylingenol-3-angelate (PEP008, 33) in solid tumor (melanoma, 
Boije af Gennäs G et al. Curr Top Med Chem. 2011; 11(11): 1370-92

The final version of record is available at http://www.eurekaselect.com/88010/article

DOI: $10.2174 / 156802611795589584$

breast, colon) cell lines [124]. In both studies, the cells exhibited irreversible, PKC-dependent

$\mathrm{G}_{1}$ and $\mathrm{G}_{2} / \mathrm{M}$ arrest, and the senescence process was dependent on the overactivation of the

ERK1/2 kinase pathway, but no correlation was detected between the induction of senescence and PKC isoform expression. Activation of the ERK 1/2 pathway has been reported to occur in both sensitive and resistant cells $[121,122,124]$; however, the kinetics of the activation appear to be important for the induction of apoptosis in leukemia cells, with sustained activation ( $>6$ hours) occurring in the sensitive cells and transient activation $(<6$ hours) in the resistant cells [121].

In addition to the activation of the ERK 1/2 pathway, ingenol-3-angelate treatment has been shown to activate other MAPK pathway kinases such as JNK [120] and p38 [119, 120]. Furthermore, inhibition of the phosphatidyl 3-kinase/ Akt signaling pathway by ingenol-3angelate has been reported in the colon cancer cell line Colo205 [120]. However, the modulation of Akt signaling was apparently PKC-independent. Recently, ingenol-3-angelate was shown to inhibit T-cell apoptosis via the activation of $\mathrm{PKC} \theta$ [117]. This PKC isoform is expressed in $\mathrm{T}$ cells but absent in myeloid leukemia cells. However, the myeloid NB4 leukemia cells were rendered resistant to apoptosis by the ectopic expression of PKC $\theta$.

\section{Immunomodulatory effects}

In addition to direct anti-leukemic actions, ingenol-3-angelate shows immunomodulatory effects [123, 125]. Ingenol-3-angelate enhances cytokine release after chemotherapy-induced cytopenia in $\mathrm{T}$ cells from AML patients. The release of IL-2 may explain the observed increase in $\mathrm{T}$ cell proliferation, whereas $\mathrm{TNF} \alpha$ and INF $\gamma$ may have anti-leukemic effects [125]. Furthermore, ingenol-3-angelate enhances the release of T-cell chemotactic chemokines and cytokines from primary AML cells [123]. Taken together, these results suggest that ingenol-3-angelate could be used as an adjuvant in AML therapy. 


\section{Effects on tumors}

When applied topically on C57BL/6 or Foxn $1^{n u}$ mice bearing subcutaneous tumors of mouse and human origin, ingenol-3-angelate regressed the tumors with great efficacy [118]. The initial mechanism of high doses ( $\left.\mathrm{LD}_{90} 180-220 \mu \mathrm{M}\right)$ of ingenol-3-angelate appears to be primary necrosis in the tumor cells. Ingenol-3-angelate is thought to rapidly disrupt the cell membrane by dissolving into it, followed by PKC-independent mitochondrial swelling and cell death [118]. The initial necrosis is associated with a local inflammatory reaction in the cells surrounding the tumor leading to recruitment of neutrophils, which kill residual tumor cells via an antibody-dependent cellular cytotoxicity mechanism [126]. Both the inflammatory phase and apoptosis are thought to depend on PKC activation.

Ingenol-3-angelate induces the activation of neutrophils via the induction of cytokine (MIP-2, TNF $\alpha$, IL-1B) release, the activation of endothelial cells vital for neutrophil adhesion and extravasation $[113,126]$, the production of tumoricidal reactive oxygen species by neutrophils, and the production of anti-cancer antibodies [126]. In addition, ingenol-3angelate has been shown to regress untreated secondary tumors by inducing the generation of anti-cancer CD8 T cells after injection into primary tumors in mice [127].

\section{Clinical trials}

Ingenol-3-angelate is currently being developed as a topical treatment for actinic keratosis $[107,128,129]$. Actinic keratoses are pre-cancerous lesions often caused by sun exposure and can lead to skin cancers such as invasive squamous cell carcinoma (SCC) if left untreated. In phase I-III trials, ingenol mebutate (ingenol-3-angelate) gel (0.005-0.05\%) has been applied for 2-3 days on the lesions and followed up to 8-12 weeks. Complete clinical 
Boije af Gennäs G et al. Curr Top Med Chem. 2011; 11(11): 1370-92

The final version of record is available at http://www.eurekaselect.com/88010/article

DOI: $10.2174 / 156802611795589584$

clearance of $28-71 \%$ of the treated lesions on head ${ }^{1}$ and non-head ${ }^{2}$ locations have been reported $[128,129]$. The treatments have been well tolerated with only minor adverse events such as erythema, scabbing/crusting and flaking/scaling/dryness. Other potential uses for ingenol-3-angelate include cutaneous warts and other non-melanoma skin cancers, such as SCC and nodular basal cell carcinoma (BCC), leukemia and bladder cancer [101].

\section{INDO- AND BENZOLACTAMS}

The teleocidin (37) family of indole alkaloids was first isolated from Streptomyces mediocidicus [130]. The compounds were found to act as tumor promoters [131] and were subsequently shown to bind to the same receptors as the phorbol esters [132]. The structurally simplest member of the family is (-)-indolactam V (ILV, 34), which can be produced in large quantities in Actinomycetes and has therefore been used as a starting point for the synthesis of new derivatives [58]. Several groups - the Irie, the Kozikowski, and the Endo groups - have carried out research into these compounds, revealed important structure-activity relationships and developed novel indolactam and benzolactam derivatives with improved selectivity profiles (see, for example, [133-135]).

\footnotetext{
${ }^{1}$ Poster presented by Spencer J. et al. at the 68th Annual Meeting of the American Academy of Dermatology meeting, March 5-9 2010, Miami, FL, USA.

${ }^{2}$ Posters presented by Swanson N. et al. and Schmieder G.J. et al. at the 68th Annual Meeting of the American Academy of Dermatology meeting, March 5-9 2010, Miami FL, USA.
} 

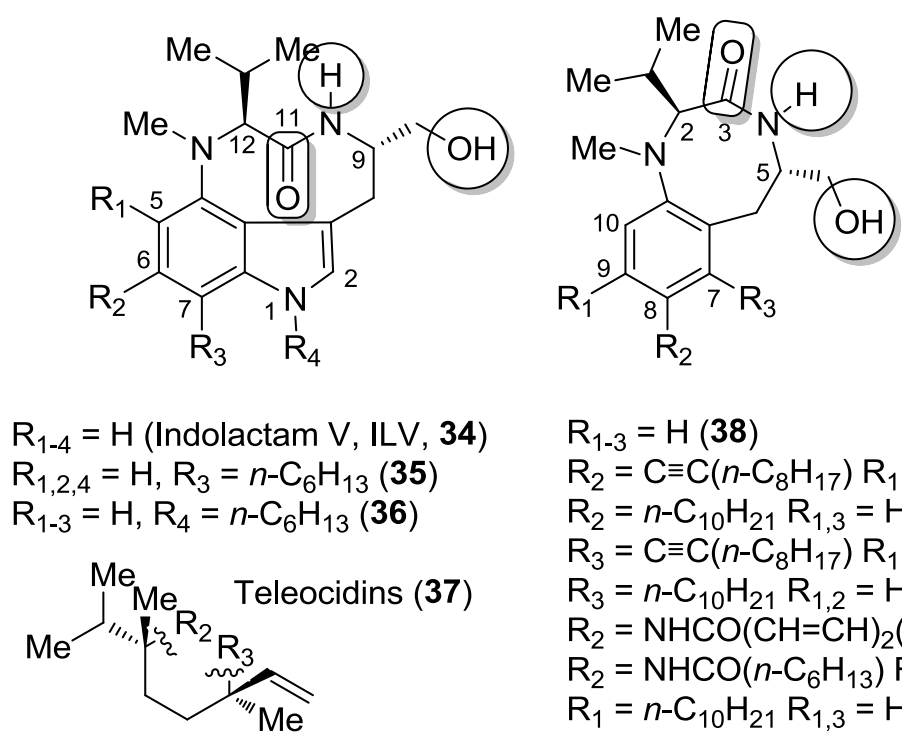

$$
\begin{aligned}
& \mathrm{R}_{1-3}=\mathrm{H}(\mathbf{3 8}) \\
& \mathrm{R}_{2}=\mathrm{C} \equiv \mathrm{C}\left(n-\mathrm{C}_{8} \mathrm{H}_{17}\right) \mathrm{R}_{1,3}=\mathrm{H}(\mathbf{3 9}) \\
& \mathrm{R}_{2}=n-\mathrm{C}_{10} \mathrm{H}_{21} \mathrm{R}_{1,3}=\mathrm{H}(\mathbf{4 0}) \\
& \mathrm{R}_{3}=\mathrm{C} \equiv \mathrm{C}\left(n-\mathrm{C}_{8} \mathrm{H}_{17}\right) \mathrm{R}_{1,2}=\mathrm{H}(\mathbf{4 1}) \\
& \mathrm{R}_{3}=n-\mathrm{C}_{10} \mathrm{H}_{21} \mathrm{R}_{1,2}=\mathrm{H}(\mathbf{4 2}) \\
& \mathrm{R}_{2}=\mathrm{NHCO}(\mathrm{CH}=\mathrm{CH})_{2}\left(4-\mathrm{CF}_{3} \mathrm{Ph}\right)(E, E) \mathrm{R}_{1,3}=\mathrm{H}(\mathbf{4 3}) \\
& \mathrm{R}_{2}=\mathrm{NHCO}\left(n-\mathrm{C}_{6} \mathrm{H}_{13}\right) \mathrm{R}_{1,3}=\mathrm{H}(\mathbf{4 4}) \\
& \mathrm{R}_{1}=n-\mathrm{C}_{10} \mathrm{H}_{21} \mathrm{R}_{1,3}=\mathrm{H}(\mathbf{4 5})
\end{aligned}
$$

Figure 6. Structures of indo- and benzolactam derivatives (34-45). Functional groups that interact with the $\mathrm{C} 1$ domain are highlighted.

\section{Structure-activity studies}

Similar to the phorbol esters (3), the indo- and benzolactams (34-45) bind to the C1b domain [136-138]. The primary hydroxyl groups of indolactams and benzolactams form hydrogen bonds to Thr242 and Leu251 in the groove of the C1b domain. In addition, the lactam N-hydrogen is hydrogen-bonded to Leu251. The lactam group was shown to be essential for binding, as the corresponding lactones showed higher $K_{\mathrm{i}}$ values [139]. Furthermore, the $\mathrm{C} 11$ and $\mathrm{C} 3$ carbonyl groups of indo- and benzolactams, respectively, act as hydrogen-bond acceptors for Gly253. In addition, the lower $K_{\mathrm{i}}$ value of ILV (34) compared to compound 38 (80 and $1700 \mathrm{nM}$, respectively) was explained by $\mathrm{CH} / \pi$ interactions between the indole ring in ILV and Pro241 in PKC $\delta[135,140]$.

The SAR of differently substituted indolactams has been studied intensively, is reviewed in [141] and will not be presented here. The following SAR results have been presented for benzolactams: 1) a hydrophobic substituent in the phenyl ring increases binding to the $\mathrm{C} 1$ domain, and position 9 is preferred before positions 8, 10 and 7 (in this order) [142]; 2) 
Boije af Gennäs G et al. Curr Top Med Chem. 2011; 11(11): 1370-92

The final version of record is available at http://www.eurekaselect.com/88010/article

DOI: $10.2174 / 156802611795589584$

substitution at positions 7 and 10 reduce binding affinity [143-145]; 3) the isopropyl at C2 can be substituted with a long alkyl chain $[146] ; 4)$ the $(2 S, 5 S)$ stereoisomer of the four possible stereoisomers is the most active [147]; 5) a linear alkyl chain with 12-14 carbons or a secondary or cyclic substituent with 11-15 carbons at C2 enhances binding affinity [148]; and 6) expanding or contracting the lactam ring size reduces binding affinity significantly $[147,149,150]$.

Kozikowski and co-workers synthesized bivalent indo- and benzolactams to study intramolecular or intermolecular binding between two C1 domains of PKC [151]. Benzolactam $44\left(K_{\mathbf{i}}=225 \mathrm{nM}\right.$ for PKC $\left.\alpha\right)$ was used as a template and was therefore coupled at C8 with an amide linker to give dimers of the derivative. A clear dependence on the linker length vs. binding affinity was obtained, and the best dimers showed $K_{\mathrm{i}}$ values between 1.8 and $38 \mathrm{nM}$ for PKC $\alpha$. These bivalent benzolactams showed a modest selectivity for PKC $\delta$ (3.2-6.6 times higher affinity for $\mathrm{PKC} \delta$, compared to $\mathrm{PKC} \alpha$ ); however, intramolecular binding between the $\mathrm{C} 1$ domains could not be obtained.

\section{Selectivity for PKC isoenzymes}

According to the SAR studies, some derivatives are selective for certain PKC isoenzymes. For example, the benzolactams 39 and $\mathbf{4 0}$ bind to cPKC isoforms $\alpha$ and $\beta$ with a certain degree of selectivity as compared to $\mathrm{nPKCs} \delta$ and $\varepsilon$ [152]. With the C7-substituted compound 42, the opposite is true: it shows an 8 -fold selectivity for the $\mathrm{nPKC}$ isoform $\varepsilon$ over the $\mathrm{cPKC}$ isoform $\alpha$ [144]. Furthermore, a series of compounds that show selectivity for C1b domains of nPKC over cPKCs has been developed. Among indolactams studied, compound 35 showed some selectivity for the C1b domain of nPKCs and $K_{\mathrm{i}}$ values of $0.18-0.59 \mathrm{nM}$ [133]. However, when the proton of the nitrogen in the indole ring is substituted with an $n$-hexyl group (compound 36), the selectivity for the $\mathrm{C} 1 \mathrm{~b}$ domains of $\mathrm{nPKCs}$ increases but with some 
Boije af Gennäs G et al. Curr Top Med Chem. 2011; 11(11): 1370-92

The final version of record is available at http://www.eurekaselect.com/88010/article

DOI: $10.2174 / 156802611795589584$

loss of binding affinity $\left(K_{\mathrm{i}}=12-29 \mathrm{nM}\right) .[138,153]$ Among the benzolactams, the same pattern can be obtained; substitution at C8 (compound 40) gives higher selectivity for the $\mathrm{C} 1 \mathrm{~b}$ domains of nPKC than substitution at C9 (compound 45) [154]. Again, selectivity was increased at the cost of binding affinity.

In addition to $\mathrm{PKC} \mathrm{C} 1$ domains, indo- and benzolactam derivatives have been shown to bind to the $\mathrm{C} 1$ domain of RasGRP with similar affinity as to the $\mathrm{PKC} \delta \mathrm{C} 1 \mathrm{~b}$ domain [136].

\section{Effects in experimental models of cancer and AD}

Benzolactam derivatives have been studied for their antiproliferative actions on cancer cells and their neuroprotective effects in cell-based models of AD. ILV and several benzolactam derivatives have been reported to inhibit the proliferation of HL-60 leukemia cells $[135,147$, 148]. The benzolactam 39 inhibits the proliferation of two breast carcinoma cell lines [152]. The same compound also activates $\mathrm{PKC} \alpha$ and restores potassium channel activity and tetraethylammonium chloride (TEA)-induced calcium responses in fibroblasts from AD patients [155]. Furthermore, it enhances sAPP secretion in fibroblasts and PC12 cells [156]. Another benzolactam $\left(\mathbf{4 3}, K_{\mathbf{i}}=11.9 \mathrm{nM}\right.$ for $\mathrm{PKC} \alpha$ [137]) increased $\alpha$-secretase activity and sAPP secretion with a concomitant decrease in $\beta$-secretase activity and $\mathrm{A} \beta 40$ release in PC12 and SH-SY5Y neuroblastoma cells transfected with human wild-type APP ${ }^{695}$ [157]. These promising in vitro results were largely confirmed in in vivo experiments with AD transgenic APP[V717I] mice in which the benzolactam 38 enhanced the secretion of sAPP and decreased the secretion of $A \beta 40$ if treatment was initiated early in life [100]. However, more in vivo studies are needed to confirm the potential of these compounds as drug candidates. 
Boije af Gennäs G et al. Curr Top Med Chem. 2011; 11(11): 1370-92

The final version of record is available at http://www.eurekaselect.com/88010/article

DOI: $10.2174 / 156802611795589584$

\section{Induction of differentiation}

Although a recognized tumor-promoter, ILV has recently been used as an inducer of human embryonic stem cell (hESC) differentiation [158]. The Melton group used high-content screening to identify small molecules that increase the number of cells expressing the pancreatic transcription factor Pdx1 (Pancreatic and duodenal homeobox 1). ILV directed hESC differentiation into the pancreatic lineage with an $\mathrm{EC}_{50}$ of $142 \mathrm{nM}$, and the effect was totally blocked with PKC antagonists. Even though the PKC isoform responsible for the effect has not yet been identified, the results suggest a role for PKC in pancreatic development and the potential of other $\mathrm{PKC}$ or $\mathrm{C} 1$ domain-targeted compounds to induce differentiation. Indeed, the authors reported that PMA and benzolactam $\mathbf{4 3}$ possess differentiation-inducing properties similar to those of ILV [158].

\section{DAG-LACTONES}

Some of the examples of rationally designed $\mathrm{C} 1$ domain-binding ligands are the DAGlactones developed by the Blumberg and Marquez groups. Their initial plan was to design conformationally constrained $\gamma$-lactones to overcome the entropial penalty caused by the flexible structure of endogenous DAG (2) upon binding to PKC (Figures 3 and 7) [26, 159]. The potency of these DAG analogues could then be increased by the addition of lipophilic side chains to improve the interaction with the conserved hydrophobic amino acids in the space between the two $\beta$-sheets of the $\mathrm{C} 1$ domain. Synthesis of the optically pure $(2 R)$-DAGlactones require 11 linear steps, significantly fewer than the number of steps required for the synthesis of, for example, the bryostatin analogues (9-27) [160]. With this approach that exploits combinatorial chemistry [161], a remarkable series of DAG-lactones has been 
Boije af Gennäs G et al. Curr Top Med Chem. 2011; 11(11): 1370-92

The final version of record is available at http://www.eurekaselect.com/88010/article

DOI: $10.2174 / 156802611795589584$

created, and intensive research has revealed important determinants for binding, intracellular localization and biological activity.

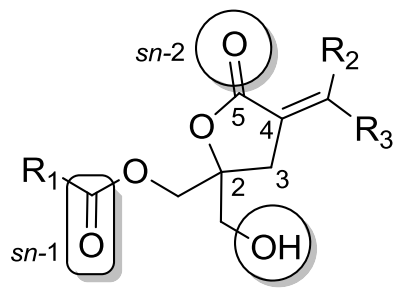

$\mathrm{R}_{1}=t-\mathrm{Bu}, \mathrm{R}_{2}=\mathrm{CH}_{2} \mathrm{CH}(i-\mathrm{Pr})_{2}, \mathrm{R}_{3}=\mathrm{H}(46)$

$\mathrm{R}_{1}, \mathrm{R}_{2}=-\left(\mathrm{CH}_{2}\right)_{14^{-}}, \mathrm{R}_{3}=\mathrm{H}(\mathbf{4 7})$

$\mathrm{R}_{1}=(i-\mathrm{Pr})_{2} \mathrm{CHCH}_{2} \mathrm{R}_{2}=\mathrm{H}, \mathrm{R}_{3}=(4-\mathrm{OMe}) \mathrm{Ph}(48)$

$\mathrm{R}_{1}=(4-(4-\mathrm{HC} \equiv \mathrm{C}) \mathrm{PhC} \equiv \mathrm{C}) \mathrm{Ph}, \mathrm{R}_{2}, \mathrm{R}_{3}=\mathrm{Me}(49)$

$\mathrm{R}_{1}=4-\left(\mathrm{Me}_{2} \mathrm{~N}\right) \mathrm{Ph}, \mathrm{R}_{2}=4-\left(\mathrm{NO}_{2}\right) \mathrm{Ph}, \mathrm{R}_{3}=\mathrm{H}(130 \mathrm{C037}, 50)$

$\mathrm{R}_{1}=\mathrm{CH}_{2} \mathrm{CH}(i-\mathrm{Pr})_{2}, \mathrm{R}_{2}=4-\left(\mathrm{CF}_{3}\right) \mathrm{Ph}, \mathrm{R}_{3}=\mathrm{H}(\mathbf{5 1})$

$\mathrm{R}_{1}=4-(\mathrm{MeO}) \mathrm{Ph}, \mathrm{R}_{2}=4-\left(\mathrm{Me}_{2} \mathrm{~N}\right) \mathrm{Ph}, \mathrm{R}_{3}=\mathrm{H}(\mathbf{5 2})$

$\mathrm{R}_{1}=4-(\mathrm{MeO}) \mathrm{Ph}, \mathrm{R}_{2}=4-(\mathrm{MeO}) \mathrm{Ph}, \mathrm{R}_{3}=\mathrm{H}(53)$

$\mathrm{R}_{1}=\mathrm{CH}_{2} \mathrm{CH}(i-\mathrm{Pr})_{2}, \mathrm{R}_{2}=\mathrm{CH}_{2}(i-\mathrm{Pr}), \mathrm{R}_{3}=\mathrm{H}(54)$

Figure 7. Structures of DAG-lactones (46-56). Functional groups that interact with the C1 domain are highlighted.

\section{Structure-activity studies}

Some DAG-lactones bind to PKC $\alpha$ with $K_{\mathrm{i}}$ values as low as $1.45 \mathrm{nM}$ (e.g., the enantiomer (2R)-46) depending on the acyl and alkylidene substituents. Molecular-modeling studies performed on the DAG-lactones reveal two competing binding modes to the $\mathrm{C} 1$ domain [162, 163]. In the $s n-1$ mode, the carbonyl of the acyl group is hydrogen-bonded to Gly 253 of the $\mathrm{C} 1$ domain, and the alkylidene group is pointing towards the lipid membranes. In the $s n-2$ mode, the lactone carbonyl is hydrogen-bonded to Gly253 and the alkyl chain of the acyl group is pointing towards the lipid membranes. Removing either of the carbonyl groups or substituting either with a thiocarbonyl reduces binding activity and further affects the binding of the $s n-1$ mode [162]. Bulky alkylidene groups enhance the $s n-2$ binding mode and increase the binding affinity to PKC. In addition, recently synthesized derivatives are suggested to 
Boije af Gennäs G et al. Curr Top Med Chem. 2011; 11(11): 1370-92

The final version of record is available at http://www.eurekaselect.com/88010/article

DOI: $10.2174 / 156802611795589584$

preferentially bind with the $s n-2$ mode [164-166], as the hydrophobic parts of the acyl group in the $s n-2$ mode are thought to interact with lipids in cellular membranes.

The following SAR results of these DAG-lactones have been reported [159]: 1) the $(2 R)$ stereoisomer is the preferred one; 2) substituents at C4 increase activity and an alkylidene substituent at C4 is preferred over an alkyl substituent; 3) over a 2-fold increase in binding affinity for the Z-alkylidenes can be obtained when the C4-alkylidene chains are branched, with some exceptions; 4) the $\mathrm{C} 3$ should not be substituted due to a lack of space in the $\mathrm{C} 1$ binding groove [167-169]; 5) the C3 can be replaced by an oxygen with some loss of activity, but with an improved clog $P$ value [170]; 6) the respective lactam and amide analogues show reduced binding affinity [171]; 7) the elimination of either the acyl or lactone carbonyl or replacing of either with a thiocarbonyl decreases activity [162]; and 8) the elongation of the C2 aliphatic acyl group decreases binding affinity [172].

The optimal clog $P$ values for binding affinity seem to be approximately 5-6 [163, 173]. Recently, the research has focused on lowering the $\log P$ values of the DAG-lactones without overly affecting the binding affinities; for example, the macrocyclic $\gamma$-lactone $(47, \operatorname{clog} P$ 3.85) [173], compound 48 (clog $P$ 3.62) [164] and compound 49 (clog $P$ 3.24) [166] were shown to bind with $K_{\mathrm{i}}$ values of $6.1,7$ and $5.2 \mathrm{nM}$, respectively. Further SAR studies are presented in the following sections.

\section{Selectivity of DAG-lactones among C1 domain containing proteins}

Several DAG-lactones show some PKC isoenzyme selective binding [165, 174]; however, differences in binding do not necessarily translate into differences in the potency to induce biological effects [175]. It has been hypothesized that the biological outcome might depend on the differential intracellular targeting of the PKC isozymes in cells. PKC has relatively broad substrate requirements and the DAG-lactones substituted with different lipophilic side 
Boije af Gennäs G et al. Curr Top Med Chem. 2011; 11(11): 1370-92

The final version of record is available at http://www.eurekaselect.com/88010/article

DOI: $10.2174 / 156802611795589584$

chains may allow PKC isoenzymes to be directed to certain intracellular compartments with different lipid environments and consequently control which substrates are accessible. This issue will be discussed later in this chapter.

Despite the high level of conservation of the $\mathrm{C} 1$ domains, some RasGRP-selective DAGlactones have been successfully designed. After initial screening of a series of biphenylsubstituted ligands [161], DAG-lactone 50 was further characterized [174]. The compound showed multiphasic and shallow binding curves for PKC isoenzymes with $K_{\mathrm{i}}$ values ranging from $340 \mathrm{nM}$ for PKC $\alpha$ to $29 \mathrm{nM}$ for PKCe. In contrast, for RasGRPs 1 and 3, which contain only one $\mathrm{C} 1$ domain, it showed monophasic binding curves with $K_{\mathrm{i}}$ values of $3.5 \mathrm{nM}$ and 3.8 $\mathrm{nM}$, respectively. A striking selectivity was also observed between the individual $\mathrm{C} 1$ domains of the PKC isoforms: the $K_{\mathrm{i}}$ values of the isolated $\mathrm{C} 1 \mathrm{a}$ and $\mathrm{C} 1 \mathrm{~b}$ domains of $\mathrm{PKC} \delta$ were 2780 and $1.78 \mathrm{nM}$, respectively, and the $K_{\mathrm{i}}$ values of the $\mathrm{C} 1 \mathrm{a}$ and $\mathrm{C} 1 \mathrm{~b}$ domains of PKC $\alpha$ were 610 and >10000 nM, respectively. The selective binding to RasGRPs was reflected in the translocation patterns of GFP-tagged proteins and in the phosphorylation of ERK1/2 induced via RasGRP3 alone. To enhance the selectivity between PKC $\alpha$ and RasGRP, a set of DAGlactones with heterocyclic moieties as $\alpha$-arylidene substituents were designed [176]. In addition, the $\alpha$-heteroarylidene moieties were combined with lipophilic-branched acyl chains to replace the aromatic acyl moieties for optimal activity. With this approach, $K_{\mathrm{i}}$ values of 0.18 and $0.72 \mathrm{nM}$ for RasGRP3 (compounds 55 and 56, respectively) and selectivity over PKC $\alpha$ by 165 -fold and 119-fold, respectively, could be achieved. Interestingly, the binding selectivity decreases when the acyl group is changed to a more branched one, which is the opposite of the result usually obtained with DAG-lactones. In addition, the $E$ heteroarylidenes showed better binding affinities to PKC $\alpha$ and RasGRP3 compared with the respective $Z$-isomers. 
Boije af Gennäs G et al. Curr Top Med Chem. 2011; 11(11): 1370-92

The final version of record is available at http://www.eurekaselect.com/88010/article

DOI: $10.2174 / 156802611795589584$

\section{Effects on cell proliferation}

Several DAG-lactones and their derivatives have shown antiproliferative and proapoptotic activity. The DAG-lactone 46, showing $K_{\mathrm{i}}$ values of $5.4 \mathrm{nM}$ for $\mathrm{PKC} \alpha$ and $1.6 \mathrm{nM}$ for PKC $\delta$ [171], exhibited proapoptotic activity in prostate cancer LNCaP cells in a PKC $\alpha$-dependent manner [177]. The effect of the enantiomer $(2 R)-46$ [160] on apoptosis was mediated by the down-regulation of ATM kinase, which is a component of the DNA damage surveillance and repair system, and led to the induction of ceramide synthesis, thus allowing DNA damagemediated apoptosis [178]. The compound (2R)-46 also sensitized prostate cancer LNCaP and CWR22-Rv1 cells to radiation-induced apoptosis. The DAG-lactone $\mathbf{5 1}$ reduced ATM levels even lower than the derivative $(2 R)-\mathbf{4 6}[175]$. Both of the ligands $((2 R)-\mathbf{4 6}$ and $\mathbf{5 1})$ also potentiated the radiation effect in vivo, where they completely inhibited prostate tumor growth in Swiss nude mice and prevented a rise in serum PSA levels [175, 178].

DAG-lactones with polar groups in the 3-alkylidene chains were synthesized to improve water solubility [179]. In most cases, the modifications had little effect on binding affinity, and ligands with good $\mathrm{PKC} \alpha$-binding affinity $\left(K_{\mathrm{i}}=3.2-5 \mathrm{nM}\right)$ also showed significant antitumor activity against colon cancer and leukemia cell lines.

\section{Induction of $\alpha$-secretase activity}

A series of branched lactones was created using the potent DAG-lactone 46 [160] as a lead structure, and the derivatives were then tested for their potential as $\alpha$-secretase activators [180]. The subnanomolar binding affinities of the derivatives to PKC $\alpha$ and their lipophilicity correlated with the induction of $\alpha$-secretase activity, which was measured as the amount of sAPP $\alpha$ secreted in human APP695-transfected W4 neuroblastoma cell line. The DAG-lactone (2R)-46 induced a dose-dependent enhancement of the $\alpha$-secretase activity and was more potent than the racemic 46 and PDBu. The enantiomer $(2 R)-46$ was further developed in 
Boije af Gennäs G et al. Curr Top Med Chem. 2011; 11(11): 1370-92

The final version of record is available at http://www.eurekaselect.com/88010/article

DOI: $10.2174 / 156802611795589584$

order to form it into a more drug-like structure with reduced lipophilicity [175]. Even if the analogues 52 and 53 showed weaker binding affinities to PKC $\alpha\left(K_{\mathrm{i}}\right.$ values of 887 and 332 $\mathrm{nM}$, respectively, compared to $1.45 \mathrm{nM}$ of the compound (2R)-46) and had $>2$ orders of magnitude reduction in the clog $P$ values, they still increased $\alpha$-secretase activity at a $1 \mu \mathrm{M}$ concentration to $154 \%$ and $162 \%$ above the untreated cells $(100 \%)$, while the template lactone increased it to $177 \%$. Based on these results, it was concluded that good binding affinity to PKC $\alpha$ does not exclusively predict the effect on $\alpha$-secretase activity.

\section{HIV-1 eradication}

Latent HIV-1-infected T-lymphocytes impose a risk of relapse and hamper the results of antiretroviral therapy. An emerging idea is to use agents that activate these latent reservoirs of the viruses by activating viral gene expression in combination with the conventional therapy for complete eradication of the virus pool. Because PKC is known to regulate HIV-1 transcription through several mechanisms, activation of PKC could result in beneficial effects in anti-HIV-1 therapy.

DAG-lactones 46 and 54, showing subnanomolar $K_{\mathrm{i}}$ values for PKC $\alpha$ (2.9 nM and 15.1 $\mathrm{nM}$, respectively $[171,181])$, induced the expression of the HIV-1 marker p24 antigen in ACH-2 cells, a latently infected T-cell line, and sensitized the cells to an anti-HIV-1 immunotoxin [182]. These ligands also induced a similar set of genes involved in T-cell activation as well as viral gene expression in PBMCs derived from HIV-1-infected patients. Because the compounds were structurally different but still showed similar biological effects, it was hypothesized that compounds $\mathbf{4 6}$ and $\mathbf{5 4}$ could favor different binding modes in the $\mathrm{C} 1$ domain. 
Boije af Gennäs G et al. Curr Top Med Chem. 2011; 11(11): 1370-92

The final version of record is available at http://www.eurekaselect.com/88010/article

DOI: $10.2174 / 156802611795589584$

\section{Correlation between ligand structure and biological response}

The extensive research on DAG-lactones has produced a great amount of knowledge about the determinants affecting the binding of the ligands to the $\mathrm{C} 1$ domain. However, the definite SAR studies are hampered by the multifaceted interactions of the $\mathrm{C} 1$ domain-ligand complex with the lipid bilayer. Because the incorporation of the lipid bilayer into the binding model is difficult, the Blumberg and Marquez groups took the indirect approach of synthesizing chemical libraries, where the synthesized compounds had different combinations of the acyl and alkylidene side chains. As a result, the concept of "chemical zip codes" was introduced to explain how subtle differences in the ligand structure could translate into different biological responses by directing the activated enzyme complex to different subcellular sites [175]. It was concluded that this concept could form the basis for therapeutic strategies targeting specific pathways.

Studies performed on DAG-lactones with different rigid rod substituents at the acyl position [165, 166] and rigid rods with different termini [183] have further helped to elucidate the mechanisms of membrane interactions of the ligand-enzyme complex, the kinetics and duration of PKC translocation, and the concomitant pattern of the biological responses such as the phosphorylation of ERK1/2, the induction of IL-6 secretion, the inhibition of cell proliferation, the induction of cell differentiation [166], and apoptosis [165]. It has also become clear that in addition to high binding affinities and appropriate clog $P$ values, the nature of the acyl groups are equally important in influencing the membrane interactions and the concomitant biological responses [165, 166, 183]. 
Boije af Gennäs G et al. Curr Top Med Chem. 2011; 11(11): 1370-92

The final version of record is available at http://www.eurekaselect.com/88010/article

DOI: $10.2174 / 156802611795589584$

\section{ANTHRACYCLINE DERIVATIVES}

Anthracyclines, such as doxorubicin (DOX, 57), are chemotherapeutic agents that are obtained from Streptomyces peucetius and S. coeruleorubidus (Figure 8) [184]. The anthracyclines exert their antitumor effects mainly via interference with a DNAtopoisomerase II interaction during DNA replication [185]. DOX intercalates into DNA with rings $\mathrm{B}$ and $\mathrm{C}$ between the adjacent base pairs of DNA and the sugar moiety located in the minor groove of DNA [186]. This stabilizes the DNA-topoisomerase-complex, and the DNA replication and cell division are halted. However, tumor cells are able to develop resistance to DOX. To overcome DOX resistance and to reduce DOX-induced cardiotoxicity, a novel semisynthetic anthracycline-derivative AD 198 (58) was synthesized [187]. It only weakly binds to DNA and has little inhibitory activity on topoisomerase II [185], therefore having a different mechanism of action from the conventional anthracyclines.

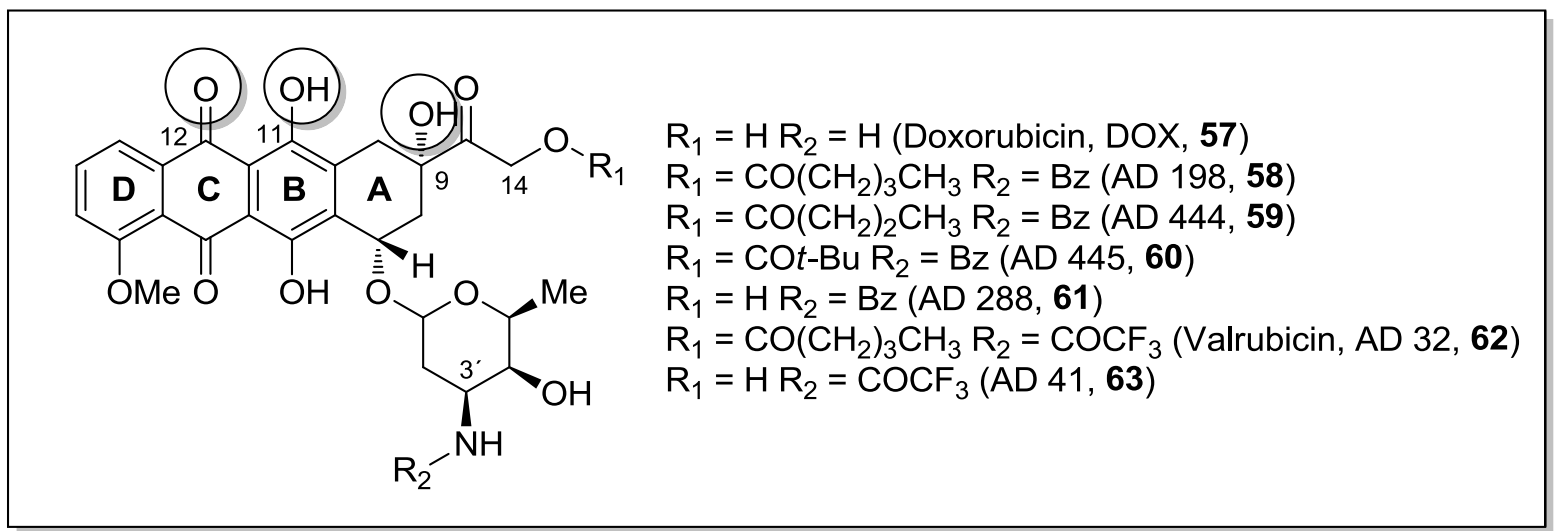

Figure 8. Structures of anthracycline derivatives (57-63). Functional groups that interact with the $\mathrm{C} 1$ domain are highlighted. In addition to these, the carbonyl of the $\mathrm{R}_{1}$ group is thought to be involved in binding to the $\mathrm{C} 1$ domain. 
Boije af Gennäs G et al. Curr Top Med Chem. 2011; 11(11): 1370-92

The final version of record is available at http://www.eurekaselect.com/88010/article

DOI: $10.2174 / 156802611795589584$

\section{Structure-activity studies}

Roaten and co-workers showed that AD 198 targets the C1 domain of PKC [188]. By using the crystal structure of the $\mathrm{PKC} \delta \mathrm{C} 1 \mathrm{~b}$ domain, they found three theoretical binding models in which $\mathrm{AD} 198$ binds in the groove of the $\mathrm{C} 1 \mathrm{~b}$ domain but less deeply than the phorbol esters (3). The authors proposed a binding model in which Ser240 and Gln257 bind to the C9 hydroxyl and Gly253 binds to the C12 carbonyl and C11 hydroxyl, which is also hydrogenbonded to Leu251. The $\mathrm{C} 14$ valerate and C3` N-benzyl group were thought to play a similar role to the acyl groups of phorbol esters in binding to $\mathrm{C} 1$ domains, and the positively charged amino group was suggested to be at least partially responsible for the translocation to the nuclear membrane. Furthermore, the valerate group of AD 198 increases the lipophilicity and causes the molecule to localize in the perinuclear region [189]. In addition, among different C14 acyl-substituted derivatives synthesized, the compounds containing 4-5 carbons (e.g., AD 198, AD 444 (59) and AD 445 (60)) were found to be most promising [190]. At the molecular level in vitro, AD 198 was shown to inhibit PKC activity and to compete with $\left[{ }^{3} \mathrm{H}\right] \mathrm{PDBu}$ binding to rat brain $\mathrm{PKC}, \mathrm{PKC} \delta$, and the $\mathrm{C} 1 \mathrm{~b}$ domain of $\mathrm{PKC} \delta$ and $\beta 2$-chimaerin [190]. AD 198 has also been reported to cause translocation of PKC $\alpha$ and PKC $\delta$ to the membrane fraction in murine myeloid cells [191]. Interestingly, DOX and AD 288 (61), the principal AD 198 metabolite, are both incapable of inhibiting PKC activity or competing for $\left[{ }^{3} \mathrm{H}\right] \mathrm{PDBu}$ binding [190].

\section{Effects on cell proliferation}

AD 198 is effective in vitro against several cancer cell lines including multidrug resistant human ovarian and breast carcinoma cells [192], mouse and human leukemia cells [193, 194] and HeLa cervical cancer cells [195]. Additionally, its anti-tumor activity has proven to be superior to that of its parent compound DOX and is not influenced by anthracycline- 
Boije af Gennäs G et al. Curr Top Med Chem. 2011; 11(11): 1370-92

The final version of record is available at http://www.eurekaselect.com/88010/article

DOI: $10.2174 / 156802611795589584$

resistance in vivo in mice [196]. The pharmacokinetics of AD 198 have been characterized in rats [197], and in vivo it is hydrolyzed to AD 288, which lacks the C14 valerate group and has a pharmacological profile similar to that of DOX [190].

The cytotoxic mechanism of $\mathrm{AD} 198$ is at least partially associated with its ability to activate $\mathrm{PKC}$ isoenzymes. It activates $\mathrm{PKC} \delta$, triggering the mitochondrial apoptotic cascade [191]. The apoptotic pathway involves $\mathrm{PKC} \delta$-dependent phosphorylation and the activation of phospholipid scramblase 3 [195, 198], which is involved in phosphatidylserine translocation to the outer leaflet of the plasma membrane during apoptosis. AD 198 also activates PKCE, which leads to cardioprotection in vivo [199] - further distinguishing it from cardiotoxic DOX. In addition to PKC, AD 198 has been reported to target several other cellular targets. For example, it inhibits mitochondrial palmitoyltransferases [200] and RNA polymerase [201]. However, the roles of these other targets in relation to the anti-cancer activity of AD 198 have not been clarified.

Another anthracycline derivative, valrubicin (AD 32, 62) [193], has similar PKC-inhibitory properties as AD 198 [202], and the mechanism of action of its valerate-free metabolite AD 41 (63) can be compared to that of AD 288 and DOX [189]. Valrubicin was reported to be safe in a phase I trial with advanced gynecological malignancies [203] and has thereafter been approved in the US for topical treatment of bladder cancer [185].

Although not primarily developed as C1 domain ligands, AD 198 and AD 32 are two promising candidates as cancer therapeutics among $\mathrm{C} 1$ domain-targeting compounds. The parent compound DOX has been used in the clinic for $>30$ years and is still one of the most widely used cancer chemotherapeutics on the market. The different mechanism of action of AD 198 and AD 32 provides a possibility to bypass drug resistance due to reduced topoisomerase II activity - a common problem related to anthracycline therapy. 
Boije af Gennäs G et al. Curr Top Med Chem. 2011; 11(11): 1370-92

The final version of record is available at http://www.eurekaselect.com/88010/article

DOI: $10.2174 / 156802611795589584$

\section{CALPHOSTIN C}

Calphostin C (64) [204] is a polycyclic aromatic perylenequinone that was described in the 1980s as a potent PKC-selective inhibitor isolated from the fungus Cladosporium cladosporioides (Figure 9) [205]. It inhibits most PKC isoforms at nanomolar concentrations, and its inhibitory effects include both the inhibition of phosphotransferase activity and the inhibition of phorbol ester binding to the $\mathrm{C} 1$ domain $[205,206]$. Its activity against PKC was later found to be light-dependent [207] and to involve the irreversible oxidative inactivation of PKC [208]. Deletion analysis of PKC confirmed that the binding site of calphostin C is the C1 domain, although the C2 domain also seemed to play a role [206]. The inactivation of PKC by calphostin $\mathrm{C}$ requires cofactors $\left(\mathrm{PS}+\mathrm{Ca}^{2+}\right.$ or PS $+\mathrm{PMA}$ ) even with constitutively active PKC mutants [206], suggesting that it targets the active conformation of PKC at the cell membranes. Among non-PKC phorbol ester receptors, calphostin $\mathrm{C}$ has been shown to inhibit diacylglycerol kinase [209] and to bind to the $\mathrm{C} 1$ domains of the chimaerins, unc-13, and RasGRP [72, 210, 211].

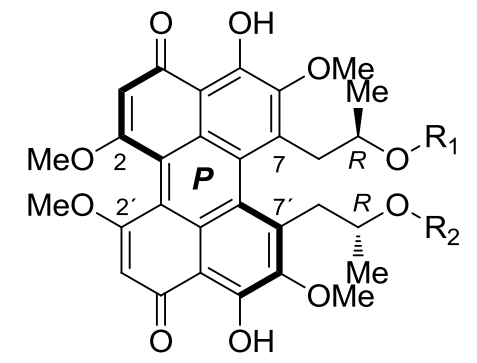

$\mathrm{R}_{1}=\mathrm{CO}_{2}(4-\mathrm{OH}-\mathrm{Ph}) \mathrm{R}_{2}=\mathrm{Bz}$ (Calphostin $\left.\mathrm{C}, 64\right)$

$\mathrm{R}_{1}=\mathrm{H} \quad \mathrm{R}_{2}=\mathrm{H}$ (Calphostin D, 65)

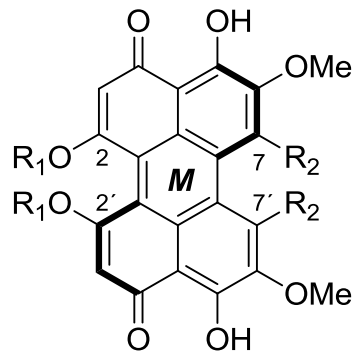

$\mathrm{R}_{1}=\mathrm{Me}, \mathrm{R}_{2}=(2 \mathrm{R}-\mathrm{OH})$ propyl (ent-Pleichrome (66)

$\mathrm{R}_{1}=$ iso-propyl, $\mathrm{R}_{2}=(2 R-\mathrm{OH})$ propyl $(67)$

$\mathrm{R}_{1}=n$-propyl, $\mathrm{R}_{2}=(2 R-\mathrm{OH})$ propyl $(68)$

$\mathrm{R}_{1}=\mathrm{Me}, \mathrm{R}_{2}=n$-propyl (69)

Figure 9. Structures of calphostins (64-65) and ent-pleichrome derivatives (66-69). 
Boije af Gennäs G et al. Curr Top Med Chem. 2011; 11(11): 1370-92

The final version of record is available at http://www.eurekaselect.com/88010/article

DOI: $10.2174 / 156802611795589584$

\section{Structure-activity studies}

The total synthesis of calphostin $\mathrm{C}$ is laborious and requires 12 steps [212, 213]. Morgan and co-workers used ent-pleichrome (66, an atropisomer of calphostin D (65)) and the crystal structure of the $\mathrm{PKC} \delta \mathrm{C} 1 \mathrm{~b}$ domain when designing new perylenequinone derivatives [214]. The docking studies showed an unfilled hydrophobic pocket in the protein, where the $\mathrm{C} 2, \mathrm{C}^{\prime}$-methoxy groups were pointing; thus, the corresponding bisisopropyl and bis- $n$-propyl derivatives (compounds 67 and 68, respectively) were synthesized and tested for binding. Both compounds showed increased binding affinities compared to 66 ( $\mathrm{IC}_{50}$ values of $0.8,1.5$ and $3.5 \mu \mathrm{M}$, respectively). Among the calphostins, higher binding affinities can be obtained with more hydrophobic groups at C7 and C7' [215]. Substitution of the 2-hydroxypropyl groups at $\mathrm{C} 7$ and $\mathrm{C}^{\prime}$ of $\mathbf{6 6}$ with $n$-propyl groups resulted in better binding, the obtained $\mathrm{IC}_{50}$ value of derivative 69 was $0.4 \mu \mathrm{M}$. [214] Furthermore, 16- to 28-fold higher binding affinities could be obtained with the $M$-atropisomers compared to the $P$-atropisomers.

\section{Effects on cell proliferation}

Calphostin $\mathrm{C}$ has been shown to have proapoptotic effects in numerous cancer cell lines such as cervical carcinoma [216], prostate cancer [217], and glioma [218]. Calphostin Cinduced cytotoxicity in breast cancer cells was reported to be accompanied by cytoplasmic vacuolization [219]. Calphostin C-induced cytoplasmic vacuolization that originates from endoplasmic reticulum (ER) stress precedes apoptosis in several different cell lines (glioblastoma, pancreatic carcinoma and breast carcinoma cell lines) [220]. However, the effect was not mediated by PKC. Indeed, there is a growing body of evidence suggesting that calphostin C-induced cytotoxicity is mediated through other mechanisms than PKC, including a general increase in reactive oxygen species (ROS) [216], the destruction of nuclear lamin B1 [216], the disassembly of Golgi apparatus [221, 222], and the direct 
Boije af Gennäs G et al. Curr Top Med Chem. 2011; 11(11): 1370-92

The final version of record is available at http://www.eurekaselect.com/88010/article

DOI: $10.2174 / 156802611795589584$

inhibition of phospholipase D [223]. Although suggested as a candidate for photodynamic cancer therapy [224, 225], there are few or no reports describing the effects of calphostin $\mathrm{C}$ in in vivo models of cancer.

\section{OTHER C1 DOMAIN LIGANDS}

Phorbol esters (3) are the most widely studied PKC activators, but due to their tumorpromoting properties, their potential in drug development is poor. However, prostratin (12deoxyphorbol-13-acetate, 70) and DPP (12-deoxyphorbol-13-benzoate, 71) are non-tumorpromoting members of the phorbol ester family with no hydroxyl/acyl group at C12 (Figure 10) $[226,227]$. Recently, the Wender group developed a five-step synthesis to prostratin and its derivatives starting from readily available phorbol (7) [226]. Prostratin inhibits de novo HIV-1 infection by PKC-dependent down-regulation of HIV receptors at the surface of target cells [228, 229]. It also induces reactivation of HI viruses in latently infected cell lines, which then renders the viruses susceptible to highly active antiretroviral therapy (HAART) [230, 231] and opens the possibility of complete eradication. However, high doses or prolonged treatments with prostratin may not be well tolerated in humans [231]. Subsequently, a series of phorbol 13-O-monoesters were shown to be effective in latent virus reactivation and to induce PKC translocation patterns typical for non-tumor promoters [227]. 


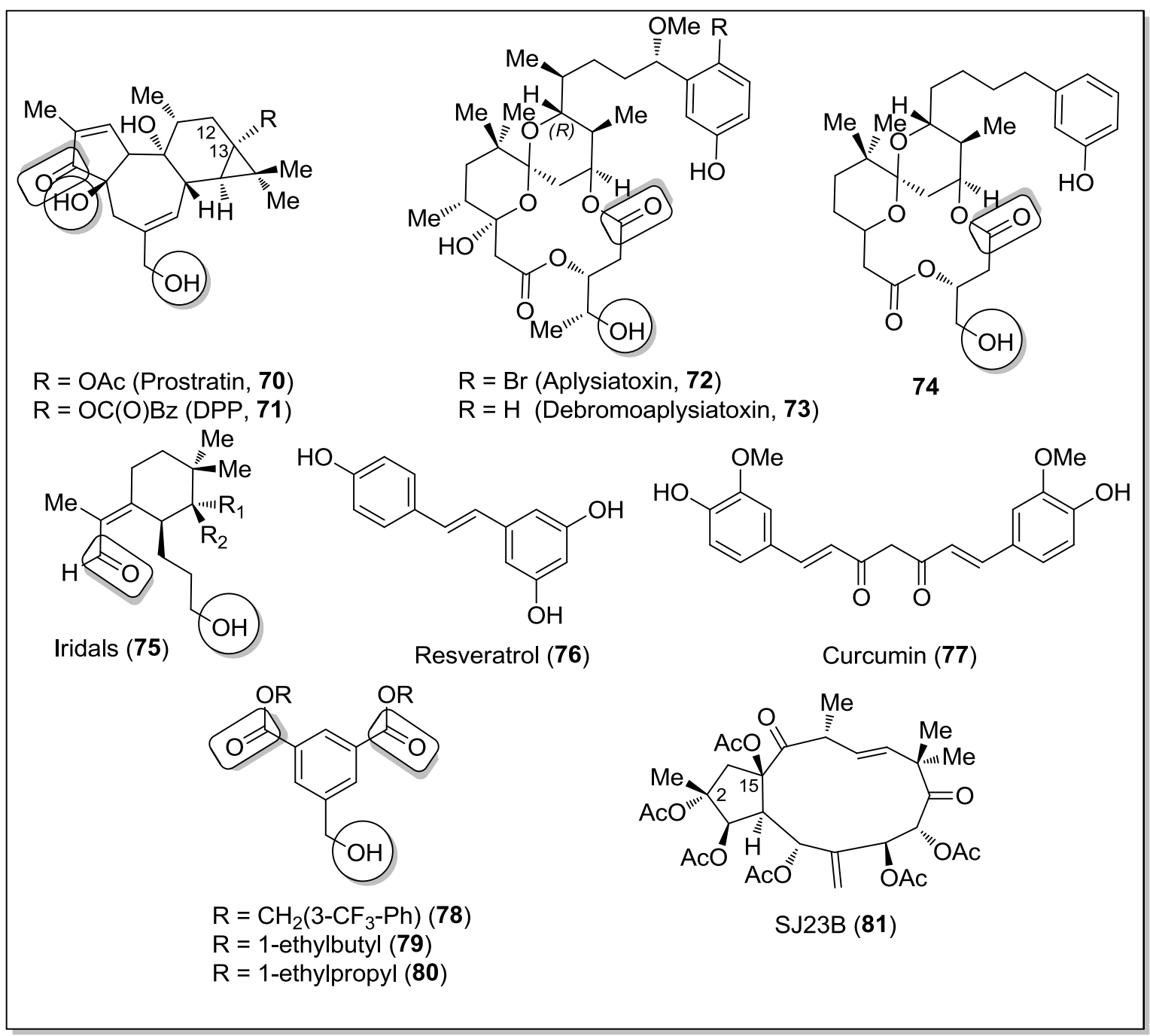

Figure 10. Structures of prostratin (70) and other derivatives (71-81). Functional groups that interact with the $\mathrm{C} 1$ domain are highlighted.

The marine spiroketals aplysiatoxin (72) and debromoaplysiatoxin (73) can be isolated from the sea hare Stylocheilus longicauda (Figure 10) [232]. These complex compounds are tumor-promoters [233] and are structurally related to bryostatins (9-10) and other C1-binding compounds. They compete with $\left[{ }^{3} \mathrm{H}\right] \mathrm{PDBu}$ for binding to its receptors [234]. Recently, a simpler, non-tumor-promoting aplysiatoxin analogue (74) was developed [235]. It showed bryostatin 1-like activity with a $K_{\mathrm{i}}$ value of $15 \mathrm{nM}$ to $\mathrm{PKC} \delta$ and anti-proliferative properties in several cancer cell lines. However, the synthesis of the analogue (74) requires 22 steps. 
The iridal type triterpenoids (75) are another class of natural products (derived from Iris sword lilies) that bind to the $\mathrm{C} 1$ domains and activate PKC (Figure 10) [236, 237]. Two iridals were shown to bind to RasGRP3 and PKC $\alpha$ with $K_{\mathrm{i}}$ values between $16-84 \mathrm{nM}$, showing modest selectivity (6-15 times) for RasGRP [238]. Furthermore, these compounds showed anti-tumor activity in several cell lines including A2780 and K562 human tumor cell lines as well as in the NCI (US) 60-cancer cell line screen. Recently, the first total synthesis of an iridal (75, $\mathrm{R}_{1}=\mathrm{Me}, \mathrm{R}_{2}=$ homofarnesyl) was performed, requiring over 20 steps [239].

Other nature-derived $\mathrm{C} 1$ domain ligands include resveratrol (76) and curcumin (77) (Figure 10). Resveratrol is a polyphenol derived from red grapes and a variety of other plants [240] that has been shown to inhibit PKC activity $\left(\mathrm{IC}_{50} 2 \mu \mathrm{M}\right)$ and compete with phorbol esters for binding to the $\mathrm{C} 1$ domains of PKC $\alpha$ [241]. Resveratrol has been extensively studied in cancer models [242], and in some cases its activity has been dependent on PKC [243, 244]. However, it targets various other molecules, which contributes to its anti-proliferative, antiinflammatory, and cardioprotective properties [240]. Curcumin is a natural polyphenol found in Curcuma longa and consumed daily by millions of people as a spice. It binds to nPKC C1b subdomains with an affinity comparable to PMA [245]. Curcumin inhibits A $\beta_{40}$ aggregation in vitro and reduces amyloid plaque burden in animal models of $\mathrm{AD}[246,247]$. Recently, curcumin was shown to induce $\mathrm{PKC} \delta$ degradation and enhance spatial learning in rats [248]. Based on its ability to suppress phorbol-induced matrix metalloproteinase- 9 expression, curcumin has also been suggested to have therapeutic potential in inhibiting invasiveness and angiogenesis of brain tumors [249]. As with resveratrol, curcumin has pleiotropic cellular effects that are independent of PKC activity [250]. Due to its anti-inflammatory, antioxidant 
Boije af Gennäs G et al. Curr Top Med Chem. 2011; 11(11): 1370-92

The final version of record is available at http://www.eurekaselect.com/88010/article

DOI: $10.2174 / 156802611795589584$

and anti-cancer properties, curcumin is in clinical trials for a variety of diseases such as cancers, irritable bowel syndrome, type II diabetes and AD [101].

A novel group of synthetic $\mathrm{C} 1$ domain ligands, the 5-(hydroxymethyl)isophthalates (78-80) were recently shown to possess the same pharmacophores as the phorbol esters (3) and DAG (2) (Figure 10 and 3) [251]. These isophthalate derivatives were designed by structure-based approach and synthesized in only four steps. They bind to PKC $\alpha$ and PKC $\delta$ with submicromolar affinities ( $K_{\mathrm{i}}$ values ranging from 210 to $920 \mathrm{nM}$ ) and regulate PKC-dependent ERK1/2 phosphorylation in living cells. In addition, isophthalate $\mathbf{7 8}$ was shown to induce apoptosis in HL-60 cells but not in Swiss 3 T3 fibroblasts [252]. Interestingly, the same side chains as in isophthalates $\mathbf{7 8}$ and $\mathbf{7 9}$ could be found among the compounds showing the best binding affinities in the DAG-lactone compound library [175].

A jatrophane diterpene SJ23B (81, Figure 10) isolated from Euphorbia semiperfoliata [253] has shown a potential PKC $\alpha$-mediated antiviral effect on HIV-1 infection and activation of latent HIV-1 gene expression, being 10-fold more potent than prostratin (70) [254]. Furthermore, it is not toxic and it does not induce cell transformation, suggesting that it lacks tumor-promoting activity. So far, no PKC-binding data has been provided. Studies with other jatrophane diterpenes revealed the importance of the acetoxy groups at C2 and C15 for the activity in HIV-1 models.

\section{CONCLUDING REMARKS}

There is exhaustive evidence suggesting that PKC isoforms could be useful therapeutic targets in different pathological disorders and an equal amount of research carried out with the aim of modulating PKC activity with different molecular entities. However, to date, no 
Boije af Gennäs G et al. Curr Top Med Chem. 2011; 11(11): 1370-92

The final version of record is available at http://www.eurekaselect.com/88010/article

DOI: $10.2174 / 156802611795589584$

PKC-targeted drugs have been approved for clinical use. The major reasons for the absence of $\mathrm{C} 1$ domain-binding drugs are the apparent inefficacy of some agents (e.g., bryostatin 1) in clinical trials and the toxicity profile of others (e.g., prostratin). In addition, some potential agents have not reached the point in the drug development pipeline for in vivo testing despite intensive in vitro research (DAG-lactones).

Regardless of the shortcomings of bryostatin 1 in cancer clinical trials, the new analogues with better selectivity might provide a solution to the toxicity and efficacy problems. Bryostatin 1 will soon be tested for its safety and efficacy in AD patients but the adverse effects especially in muscles might still restrict its use. However, bryostatin 1 could still be useful in the treatment of cerebral ischemia because the effective doses of bryostatin 1 in rats were within the doses tolerated by humans.

In a recent study, cultured colon cancer cells developed resistance to the antiproliferative effects of ingenol-3-angelate and other PKC-modulating agents [255]. The researchers speculated that the acquired resistance to PKC modulators could explain the failure of the clinical trials in patients with cancer. Therefore, in addition to the careful selection of the patients, the protocols of clinical trials should include the examination of the effects of the trial agents on PKC isoform expression/activity in tumor cells in order to get a better picture of the effects of each treatment.

The clinical trials of topical treatment of actinic keratosis with ingenol-3-angelate look very promising and the compound will probably soon reach the market. Developed by the pharmaceutical companies Peplin and Leo Pharma Ltd, ingenol-3-angelate is also being studied for possible systemic administration to treat leukemias and for an intracavitary formulation to treat bladder cancer. This is one of the stories where the centuries-old folk remedy will be refined into a clinically approved drug. 
Boije af Gennäs G et al. Curr Top Med Chem. 2011; 11(11): 1370-92

The final version of record is available at http://www.eurekaselect.com/88010/article

DOI: $10.2174 / 156802611795589584$

Most of the $\mathrm{C} 1$ domain-binding compounds are derived from nature. The plant family Euphorbiaceae seems to especially be an endless source of pharmacologically active secondary metabolites. Various marine organisms have also been a valuable source of PKCbinding compounds. However, quite often, the isolation of the compound is very laborious and the yields are extremely small. Total synthesis of the natural products is often unfeasible due to their complex structures, but the work with several natural products such as bryostatins has proved that the pharmacophores (of the natural products) may be simplified and translated into more drug-like structures that also have shorter synthesis routes.

Rational design of $\mathrm{C} 1$ domain-binding compounds is a reasonable alternative to the natural products, although it still faces great challenges. The crystal structure of the whole PKC enzyme still waits to be solved. Furthermore, the lipid membrane in which the $\mathrm{C} 1$ domainligand complex is partly buried is difficult to include in the binding model. However, the work carried out with the DAG-lactones has greatly improved the knowledge of the crucial determinants for the ligand-protein-membrane interaction and the concomitant biological responses. Taking into account the specific structural features of each $\mathrm{C} 1$ domain in their whole-protein context, including the amino acid residues crucial for ligand recognition [136, 256], more selective compounds could probably be designed, and these could even direct a subset of the $\mathrm{C} 1$ domains to desired subcellular compartments. An attractive approach is also the creation of bivalent $\mathrm{C} 1$ domain-binding compounds that could be targeted to tandem $\mathrm{C} 1$ domains with different spacing.

One important aspect in targeting the $\mathrm{C} 1$ domain is the possibility for the development of PKC agonists. However, PKC activators face the challenge of tumor promotion, which may restrict their use. Therefore, balancing the anti- and pro-tumor properties is necessary, and it is clear that long-term experiments are necessary. 
Boije af Gennäs G et al. Curr Top Med Chem. 2011; 11(11): 1370-92

The final version of record is available at http://www.eurekaselect.com/88010/article

DOI: $10.2174 / 156802611795589584$

Taken together, the development of $\mathrm{C} 1$ domain-targeted compounds is still going strong.

With ever-increasing knowledge of the roles of $\mathrm{C} 1$ domain-containing proteins in different biological functions and of the crosstalk these proteins may have with each other in response to DAG signaling, the new chemical innovations and improved old ones will with no doubt provide us with new drug candidates in the near future.

\section{ACKNOWLEDGEMENTS}

Work in this laboratory was supported by the European Commission (LSHB-CT-200450367), the Päivikki and Sakari Sohlberg Foundation, the Magnus Ehrnrooth Foundation, The Finnish Pharmaceutical Society and the Finnish Cultural Foundation, which are gratefully acknowledged.

\section{REFERENCES}

[1] Nishizuka, Y. The role of protein kinase $\mathrm{C}$ in cell surface signal transduction and tumour promotion. Nature 1984, 308, 693-698.

[2] Steinberg, S. F. Structural basis of protein kinase C isoform function. Physiol. Rev. 2008, $88,1341-1378$.

[3] Newton, A. C. Protein kinase C: structural and spatial regulation by phosphorylation, cofactors, and macromolecular interactions. Chem. Rev. 2001, 101, 2353-2364.

[4] Hofmann, J. Protein kinase C isozymes as potential targets for anticancer therapy. Curr. Cancer. Drug Targets 2004, 4, 125-146.

[5] Griner, E. M.; Kazanietz, M. G. Protein kinase C and other diacylglycerol effectors in cancer. Nat. Rev. Cancer 2007, 7, 281-294.

[6] Baier, G.; Wagner, J. PKC inhibitors: potential in T cell-dependent immune diseases. Curr. Opin. Cell Biol. 2009, 21, 262-267. 
Boije af Gennäs G et al. Curr Top Med Chem. 2011; 11(11): 1370-92

The final version of record is available at http://www.eurekaselect.com/88010/article

DOI: $10.2174 / 156802611795589584$

[7] Hayashi, K.; Altman, A. Protein kinase $C$ theta (PKC $\theta)$ : a key player in T cell life and death. Pharmacol. Res. 2007, 55, 537-544.

[8] Sabri, A.; Steinberg, S. F. Protein kinase C isoform-selective signals that lead to cardiac hypertrophy and the progression of heart failure. Mol. Cell. Biochem. 2003, 251, 97-101.

[9] Churchill, E.; Budas, G.; Vallentin, A.; Koyanagi, T.; Mochly-Rosen, D. PKC isozymes in chronic cardiac disease: possible therapeutic targets? Annu. Rev. Pharmacol. Toxicol. 2008, 48, 569-599.

[10] Chou, W. H.; Messing, R. O. Protein kinase C isozymes in stroke. Trends Cardiovasc. Med. 2005, 15, 47-51.

[11] Battaini, F. Protein kinase C isoforms as therapeutic targets in nervous system disease states. Pharmacol. Res. 2001, 44, 353-361.

[12] Pascale, A.; Amadio, M.; Govoni, S.; Battaini, F. The aging brain, a key target for the future: the protein kinase C involvement. Pharmacol. Res. 2007, 55, 560-569.

[13] Olariu, A.; Yamada, K.; Nabeshima, T. Amyloid pathology and protein kinase C (PKC): possible therapeutics effects of PKC activators. J. Pharmacol. Sci. 2005, 97, 1-5.

[14] Alkon, D. L.; Sun, M. K.; Nelson, T. J. PKC signaling deficits: a mechanistic hypothesis for the origins of Alzheimer's disease. Trends Pharmacol. Sci. 2007, 28, 51-60.

[15] Clarke, M.; Dodson, P. M. PKC inhibition and diabetic microvascular complications. Best Pract. Res. Clin. Endocrinol. Metab. 2007, 21, 573-586.

[16] Herbst, R. S.; Oh, Y.; Wagle, A.; Lahn, M. Enzastaurin, a protein kinase C $\beta$ - selective inhibitor, and its potential application as an anticancer agent in lung cancer. Clin. Cancer Res. 2007, 13, s4641-4646.

[17] Manning, G.; Whyte, D. B.; Martinez, R.; Hunter, T.; Sudarsanam, S. The protein kinase complement of the human genome. Science 2002, 298, 1912-1934. 
Boije af Gennäs G et al. Curr Top Med Chem. 2011; 11(11): 1370-92

The final version of record is available at http://www.eurekaselect.com/88010/article

DOI: $10.2174 / 156802611795589584$

[18] Wang, Q. J. PKD at the crossroads of DAG and PKC signaling. Trends Pharmacol. Sci. 2006, 27, 317-323.

[19] Yang, C.; Kazanietz, M. G. Chimaerins: GAPs that bridge diacylglycerol signalling and the small G-protein Rac. Biochem. J. 2007, 403, 1-12.

[20] Sakane, F.; Imai, S.; Kai, M.; Yasuda, S.; Kanoh, H. Diacylglycerol kinases as emerging potential drug targets for a variety of diseases. Curr. Drug Targets 2008, 9, 626-640.

[21] Stone, J. C. Regulation of Ras in lymphocytes: get a GRP. Biochem. Soc. Trans. 2006, $34,858-861$.

[22] Betz, A.; Ashery, U.; Rickmann, M.; Augustin, I.; Neher, E.; Sudhof, T. C.; Rettig, J.; Brose, N. Munc13-1 is a presynaptic phorbol ester receptor that enhances neurotransmitter release. Neuron 1998, 21, 123-136.

[23] Leung, T.; Chen, X. Q.; Tan, I.; Manser, E.; Lim, L. Myotonic dystrophy kinase-related Cdc42-binding kinase acts as a Cdc42 effector in promoting cytoskeletal reorganization. Mol. Cell. Biol. 1998, 18, 130-140.

[24] Toker, A. The biology and biochemistry of diacylglycerol signalling. Meeting on molecular advances in diacylglycerol signalling. EMBO Rep. 2005, 6, 310-314.

[25] Warrilow, D.; Gardner, J.; Darnell, G. A.; Suhrbier, A.; Harrich, D. HIV type 1 inhibition by protein kinase C modulatory compounds. AIDS Res. Hum. Retroviruses 2006 22, 854-64.

[26] Blumberg, P. M.; Kedei, N.; Lewin, N. E.; Yang, D.; Czifra, G.; Pu, Y.; Peach, M. L.; Marquez, V. E. Wealth of opportunity - the $\mathrm{C} 1$ domain as a target for drug development. Curr. Drug Targets 2008, 9, 641-652.

[27] Zeidman, R.; Löfgren, B.; Påhlman, S.; Larsson, C. PKCe, via its regulatory domain and independently of its catalytic domain, induces neurite-like processes in neuroblastoma cells. J. Cell Biol. 1999, 145, 713-726. 
[28] Cameron, A. J.; Procyk, K. J.; Leitges, M.; Parker, P. J. PKC alpha protein but not kinase activity is critical for glioma cell proliferation and survival. Int. J. Cancer 2008, 123, 769-779.

[29] Cameron, A. J.; Parker, P. J. Protein kinase C - a family of protein kinases, allosteric effectors or both? Adv. Enzyme Regul. 2010, 50, 169-177.

[30] Colon-Gonzalez, F.; Kazanietz, M. G. C1 domains exposed: from diacylglycerol binding to protein-protein interactions. Biochim. Biophys. Acta 2006, 1761, 827-837.

[31] Zhang, G.; Kazanietz, M. G.; Blumberg, P. M.; Hurley, J. H. Crystal structure of the cys 2 activator-binding domain of protein kinase $\mathrm{C} \delta$ in complex with phorbol ester. Cell 1995, 81, 917-924.

[32] Lomize, A. L.; Pogozheva, I. D.; Lomize, M. A.; Mosberg, H. I. The role of hydrophobic interactions in positioning of peripheral proteins in membranes. BMC Struct. Biol. 2007, 7, 44-74.

[33] Sugita, K.; Neville, C. F.; Sodeoka, M.; Sasai, H.; Shibasaki, M. Stereocontrolled syntheses of phorbol analogs and evaluation of their binding affinity to PKC. Tetrahedron Lett. 1995, 36, 1067-1070.

[34] Sodeoka, M.; Uotsu, K.; Shibasaki, M. Photoaffinity labeling of PKC with a phorbol derivative: importance of the 13-acyl group in phorbol ester-PKC interaction. Tetrahedron Lett. 1995, 36, 8795-8798.

[35] Kazanietz, M. G.; Barchi, J. J.; Omichinski, J. G.; Blumberg, P. M. Low affinity binding of phorbol esters to protein kinase $\mathrm{C}$ and its recombinant cysteine-rich region in absence of phospholipids. J. Biol. Chem. 1995, 270, 14679-14684. 
Boije af Gennäs G et al. Curr Top Med Chem. 2011; 11(11): 1370-92

The final version of record is available at http://www.eurekaselect.com/88010/article

DOI: $10.2174 / 156802611795589584$

[36] Hritz, J.; Ulicny, J.; Laaksonen, A.; Jancura, D.; Miskovsky, P. Molecular interaction model for the $\mathrm{C} 1 \mathrm{~B}$ domain of protein kinase $\mathrm{C}-\gamma$ in the complex with its activator phorbol-12myristate-13-acetate in water solution and lipid bilayer. J. Med. Chem. 2004, 47, 6547-6555.

[37] Xu, R. X.; Pawelczyk, T.; Xia, T. H.; Brown, S. C. NMR structure of a protein kinase C$\gamma$ phorbol-binding domain and study of protein-lipid micelle interactions. Biochemistry 1997, 36, 10709-10717.

[38] Fischer, S. M.; Patrick, K. E.; Lee, M. L.; Cameron, G. S. 4- $\beta$ - and 4- $\alpha-12-O-$ tetradecanoylphorbol-13-acetate elicit arachidonate release from epidermal cells through different mechanisms. Cancer Res. 1991, 51, 850-856.

[39] Tanaka, M.; Irie, K.; Nakagawa, Y.; Nakamura, Y.; Ohigashi, H.; Wender, P. A. The C4 hydroxyl group of phorbol esters is not necessary for protein kinase $\mathrm{C}$ binding. Bioorg. Med. Chem. Lett. 2001, 11, 719-722.

[40] Canagarajah, B.; Leskow, F. C.; Ho, J. Y.; Mischak, H.; Saidi, L. F.; Kazanietz, M. G.; Hurley, J. H. Structural mechanism for lipid activation of the Rac-specific GAP, $\beta 2-$ chimaerin. Cell 2004, 119, 407-418.

[41] Pettit, G. R.; Herald, C. L.; Doubek, D. L.; Herald, D. L. Isolation and structure of bryostatin 1. J. Am. Chem. Soc. 1982, 104, 6846-6848.

[42] Davidson, S. K.; Allen, S. W.; Lim, G. E.; Anderson, C. M.; Haygood, M. G. Evidence for the biosynthesis of bryostatins by the bacterial symbiont "Candidatus Endobugula sertula" of the bryozoan Bugula neritina. Appl. Environ. Microbiol. 2001, 67, 4531-7.

[43] Wender, P. A.; Verma, V. A. The design, synthesis, and evaluation of C7 diversified bryostatin analogs reveals a hot spot for PKC affinity. Org. Lett. 2008, 10, 3331-3334.

[44] Mutter, R.; Wills, M. Chemistry and clinical biology of the bryostatins. Bioorg. Med. Chem. 2000, 8, 1841-60. 
Boije af Gennäs G et al. Curr Top Med Chem. 2011; 11(11): 1370-92

The final version of record is available at http://www.eurekaselect.com/88010/article

DOI: $10.2174 / 156802611795589584$

[45] Evans, D. A.; Carter, P. H.; Carreira, E. M.; Charette, A. B.; Prunet, J. A.; Lautens, M. Total synthesis of bryostatin 2. J. Am. Chem. Soc. 1999, 121, 7540-7552.

[46] Hale, K. J.; Manaviazar, S. New approaches to the total synthesis of the bryostatin antitumor macrolides. Chem. Asian J. 2010, 5, 704-754.

[47] Wender, P. A.; Baryza, J. L.; Brenner, S. E.; Clarke, M. O.; Craske, M. L.; Horan, J. C.; Meyer, T. Function oriented synthesis: the design, synthesis, PKC binding and translocation activity of a new bryostatin analog. Curr. Drug Discovery Technol. 2004, 1, 1-11.

[48] Wender, P. A.; Baryza, J. L.; Bennett, C. E.; Bi, F. C.; Brenner, S. E.; Clarke, M. O.; Horan, J. C.; Kan, C.; Lacôte, E.; Lippa, B.; Nell, P. G.; Turner, T. M. The practical synthesis of a novel and highly potent analogue of bryostatin. J. Am. Chem. Soc. 2002, 124, 13648-13649.

[49] Wender, P. A.; Brabander, J. D.; Harran, P. G.; Jimenez, J.; Koehler, M. F. T.; Lippa, B.; Park, C.; Shiozaki, M. Synthesis of the first members of a new class of biologically active bryostatin analogues. J. Am. Chem. Soc. 1998, 120, 4534-4535.

[50] Keck, G. E.; Kraft, M. B.; Truong, A. P.; Li, W.; Sanchez, C. C.; Kedei, N.; Lewin, N. E.; Blumberg, P. M. Convergent assembly of highly potent analogues of bryostatin 1 via pyran annulation: bryostatin look-alikes that mimic phorbol ester function. J. Am. Chem. Soc. 2008, 130, 6660-6661.

[51] Keck, G. E.; Li, W.; Kraft, M. B.; Kedei, N.; Lewin, N. E.; Blumberg, P. M. The bryostatin 1 A-ring acetate is not the critical determinant for antagonism of phorbol esterinduced biological responses. Org. Lett. 2009, 11, 2277-80.

[52] Keck, G. E.; Poudel, Y. B.; Welch, D. S.; Kraft, M. B.; Truong, A. P.; Stephens, J. C.; Kedei, N.; Lewin, N. E.; Blumberg, P. M. Substitution on the A-ring confers to bryopyran analogues the unique biological activity characteristic of bryostatins and distinct from that of the phorbol esters. Org. Lett. 2009, 11, 593-596. 
Boije af Gennäs G et al. Curr Top Med Chem. 2011; 11(11): 1370-92

The final version of record is available at http://www.eurekaselect.com/88010/article

DOI: $10.2174 / 156802611795589584$

[53] Wender, P. A.; Dechristopher, B. A.; Schrier, A. J. Efficient synthetic access to a new family of highly potent bryostatin analogues via a Prins-driven macrocyclization strategy. $J$. Am. Chem. Soc. 2008, 130, 6658-6659.

[54] Wender, P. A.; Horan, J. C.; Verma, V. A. Total synthesis and initial biological evaluation of new B-ring-modified bryostatin analogs. Org. Lett. 2006, 8, 5299-5302.

[55] Wender, P. A.; Baryza, J. L. Identification of a tunable site in bryostatin analogs: C20 Bryologs through late stage diversification. Org. Lett. 2005, 7, 1177-1180.

[56] Kazanietz, M. G.; Lewin, N. E.; Gao, F.; Pettit, G. R.; Blumberg, P. M. Binding of [26$3 \mathrm{H}]$ bryostatin 1 and analogs to calcium-dependent and calcium-independent protein kinase $\mathrm{C}$ isozymes. Mol. Pharmacol. 1994, 46, 374-379.

[57] Dell'Aquila, M. L.; Nguyen, H. T.; Herald, C. L.; Pettit, G. R.; Blumberg, P. M. Inhibition by bryostatin 1 of the phorbol ester-induced blockage of differentiation in hexamethylene bisacetamide-treated Friend erythroleukemia cells. Cancer Res. 1987, 47, 6006-6009.

[58] Kennedy, M. J.; Prestigiacomo, L. J.; Tyler, G.; May, W. S.; Davidson, N. E. Differential effects of bryostatin 1 and phorbol ester on human breast cancer cell lines. Cancer Res. 1992, 52, 1278-1283.

[59] Szallasi, Z.; Denning, M. F.; Smith, C. B.; Dlugosz, A. A.; Yuspa, S. H.; Pettit, G. R.; Blumberg, P. M. Bryostatin 1 protects protein kinase $\mathrm{C}-\delta$ from down-regulation in mouse keratinocytes in parallel with its inhibition of phorbol ester-induced differentiation. Mol. Pharmacol. 1994, 46, 840-850.

[60] Szallasi, Z.; Smith, C. B.; Pettit, G. R.; Blumberg, P. M. Differential regulation of protein kinase $\mathrm{C}$ isozymes by bryostatin 1 and phorbol 12-myristate 13-acetate in NIH 3T3 fibroblasts. J. Biol. Chem. 1994, 269, 2118-2124. 
Boije af Gennäs G et al. Curr Top Med Chem. 2011; 11(11): 1370-92

The final version of record is available at http://www.eurekaselect.com/88010/article

DOI: $10.2174 / 156802611795589584$

[61] Lorenzo, P. S.; Bogi, K.; Acs, P.; Pettit, G. R.; Blumberg, P. M. The catalytic domain of protein kinase $\mathrm{C} \delta$ confers protection from down-regulation induced by bryostatin 1. J. Biol. Chem. 1997, 272, 33338-43.

[62] Lorenzo, P.S.; Bogi, K.; Hughes, K. M.; Beheshti, M.; Bhattacharyya, D.; Garfield, S. H.; Pettit, G. R.; Blumberg, P. M. Differential roles of the tandem C1 domains of protein kinase $\mathrm{C} \delta$ in the biphasic down-regulation induced by bryostatin 1. Cancer Res. 1999, 59, 6137-6144.

[63] Choi, S. H.; Hyman, T.; Blumberg, P. M. Differential effect of bryostatin 1 and phorbol 12-myristate 13-acetate on HOP-92 cell proliferation is mediated by down-regulation of protein kinase C $\delta$. Cancer Res. 2006, 66, 7261-7269.

[64] Tuthill, M. C.; Oki, C. E.; Lorenzo, P. S. Differential effects of bryostatin 1 and 12-Otetradecanoylphorbol-13-acetate on the regulation and activation of RasGRP1 in mouse epidermal keratinocytes. Mol. Cancer Ther. 2006, 5, 602-610.

[65] Bogi, K.; Lorenzo, P. S.; Szallasi, Z.; Acs, P.; Wagner, G. S.; Blumberg, P. M. Differential selectivity of ligands for the $\mathrm{C} 1 \mathrm{a}$ and $\mathrm{C} 1 \mathrm{~b}$ phorbol ester binding domains of protein kinase $\mathrm{C} \delta$ : possible correlation with tumor-promoting activity. Cancer Res. 1998, 58, $1423-1428$.

[66] Lee, H. W.; Smith, L.; Pettit, G. R.; Bingham Smith, J. Dephosphorylation of activated protein kinase C contributes to downregulation by bryostatin. Am. J. Physiol. 1996, 271, C304-11.

[67] Isakov, N.; Galron, D.; Mustelin, T.; Pettit, G. R.; Altman, A. Inhibition of phorbol ester-induced $\mathrm{T}$ cell proliferation by bryostatin is associated with rapid degradation of protein kinase C. J. Immunol. 1993, 150, 1195-1204.

[68] Sredni, B.; Kalechman, Y.; Albeck, M.; Gross, O.; Aurbach, D.; Sharon, P.; Sehgal, S. N.; Gurwith, M. J.; Michlin, H. Cytokine secretion effected by synergism of the 
Boije af Gennäs G et al. Curr Top Med Chem. 2011; 11(11): 1370-92

The final version of record is available at http://www.eurekaselect.com/88010/article

DOI: $10.2174 / 156802611795589584$

immunomodulator AS101 and the protein kinase C inducer bryostatin. Immunology 1990, 70, 473-477.

[69] Basu, A.; Akkaraju, G. R. Regulation of caspase activation and cisdiamminedichloroplatinum(II)-induced cell death by protein kinase C. Biochemistry 1999, $38,4245-4251$.

[70] Matthews, S. A.; Pettit, G. R.; Rozengurt, E. Bryostatin 1 induces biphasic activation of protein kinase D in intact cells. J. Biol. Chem. 1997, 272, 20245-20250.

[71] Jaggi, M.; Chauhan, S. C.; Du, C.; Balaji, K. C. Bryostatin 1 modulates $\beta$-catenin subcellular localization and transcription activity through protein kinase D1 activation. Mol. Cancer Ther. 2008, 7, 2703-2712.

[72] Lorenzo, P. S.; Beheshti, M.; Pettit, G. R.; Stone, J. C.; Blumberg, P. M. The guanine nucleotide exchange factor RasGRP is a high -affinity target for diacylglycerol and phorbol esters. Mol. Pharmacol. 2000, 57, 840-846.

[73] Stone, J. C.; Stang, S. L.; Zheng, Y.; Dower, N. A.; Brenner, S. E.; Baryza, J. L.; Wender, P. A. Synthetic bryostatin analogues activate the RasGRP1 signaling pathway. $J$. Med. Chem. 2004, 47, 6638-6644.

[74] Caloca, M. J.; Wang, H.; Delemos, A.; Wang, S.; Kazanietz, M. G. Phorbol esters and related analogs regulate the subcellular localization of $\beta 2$-chimaerin, a non-protein kinase $\mathrm{C}$ phorbol ester receptor. J. Biol. Chem. 2001, 276, 18303-18312.

[75] Trost, B.M.; Yang, H.; Thiel, O. R.; Frontier, A. J.; Brindle, C. S. Synthesis of a ringexpanded bryostatin analogue. J. Am. Chem. Soc. 2007, 129, 2206-2207.

[76] Jones, R. J.; Sharkis, S. J.; Miller, C. B.; Rowinsky, E. K.; Burke, P. J.; May, W. S. Bryostatin 1, a unique biologic response modifier: anti-leukemic activity in vitro. Blood 1990, 75, 1319-1323. 
Boije af Gennäs G et al. Curr Top Med Chem. 2011; 11(11): 1370-92

The final version of record is available at http://www.eurekaselect.com/88010/article

DOI: $10.2174 / 156802611795589584$

[77] Roddie, P. H.; Horton, Y.; Turner, M. L. Primary acute myeloid leukaemia blasts resistant to cytokine-induced differentiation to dendritic-like leukaemia cells can be forced to differentiate by the addition of bryostatin-1. Leukemia 2002, 16, 84-93.

[78] Hayun, M.; Okun, E.; Hayun, R.; Gafter, U.; Albeck, M.; Longo, D. L.; Sredni, B. Synergistic effect of AS101 and Bryostatin-1 on myeloid leukemia cell differentiation in vitro and in an animal model. Leukemia 2007, 21, 1504-1513.

[79] Thomas, A.; Pepper, C.; Hoy, T.; Bentley, P. Bryostatin induces protein kinase C modulation, Mcl-1 up-regulation and phosphorylation of $\mathrm{Bcl}-2$ resulting in cellular differentiation and resistance to drug-induced apoptosis in B-cell chronic lymphocytic leukemia cells. Leuk. Lymphoma 2004, 45, 997-1008.

[80] Szallasi, Z; Du, L.; Levine, R.; Lewin, N. E.; Nguyen, P. N.; Williams, M. D.; Pettit, G. R.; Blumberg, P. M. The bryostatins inhibit growth of B16/F10 melanoma cells in vitro through a protein kinase $\mathrm{C}$-independent mechanism: dissociation of activities using 26-epibryostatin 1. Cancer Res. 1996, 56, 2105-2111.

[81] Stang, S. L.; Lopez-Campistrous, A.; Song, X.; Dower, N. A.; Blumberg, P. M.; Wender, P. A.; Stone, J. C. A proapoptotic signaling pathway involving RasGRP, Erk, and Bim in B cells. Exp. Hematol. 2009, 37, 122-134.

[82] Jørgensen, H. G.; Allan, E. K.; Mountford, J. C.; Richmond, L.; Harrison, S.; Elliott, M. A.; Holyoake, T. L. Enhanced CML stem cell elimination in vitro by bryostatin priming with imatinib mesylate. Exp. Hematol. 2005, 33, 1140-1146.

[83] Al-Katib, A. M.; Smith, M. R.; Kamanda, W. S.; Pettit, G. R.; Hamdan, M.; Mohamed, A. N.; Chelladurai, B.; Mohammad, R. M. Bryostatin 1 down-regulates mdr1 and potentiates vincristine cytotoxicity in diffuse large cell lymphoma xenografts. Clin. Cancer Res. 1998, 4, $1305-1314$ 
Boije af Gennäs G et al. Curr Top Med Chem. 2011; 11(11): 1370-92

The final version of record is available at http://www.eurekaselect.com/88010/article

DOI: $10.2174 / 156802611795589584$

[84] Wang, S.; Wang, Z.; Dent, P.; Grant, S. Induction of tumor necrosis factor by bryostatin 1 is involved in synergistic interactions with paclitaxel in human myeloid leukemia cells. Blood 2003, 101, 3648-3657.

[85] Trenn, G.; Pettit, G. R.; Takayama, H.; Hu-Li, J.; Sitkovsky, M. V. Immunomodulating properties of a novel series of protein kinase C activators. The bryostatins. J. Immunol. 1988, 140, 433-439.

[86] Garcia, C. S.; Curiel, R. E.; Mwatibo, J. M.; Pestka, S.; Li, H.; Espinoza-Delgado, I. The antineoplastic agent bryostatin-1 differentially regulates IFN- $\gamma$ receptor subunits in monocytic cells: transcriptional and posttranscriptional control of IFN- $\gamma$ R2. J. Immunol. 2006, 177, 2707-2716.

[87] Bosco, M. C.; Rottschafer, S.; Taylor, L. S.; Ortaldo, J. R.; Longo, D. L.; EspinozaDelgado, I. The antineoplastic agent bryostatin-1 induces proinflammatory cytokine production in human monocytes: synergy with interleukin-2 and modulation of interleukin2R $\gamma$ chain expression. Blood 1997, 89, 3402-3411.

[88] Shaha, S. P.; Tomic, J.; Shi, Y.; Pham, T.; Mero, P.; White, D.; He, L.; Baryza, J. L.; Wender, P. A.; Booth, J. W.; Spaner, D. E. Prolonging microtubule dysruption enhances the immunogenicity of chronic lymphocytic leukaemia cells. Clin. Exp. Immunol. 2009, 158, 186-198.

[89] Swannie, H. C.; Kaye, S. B. Protein kinase C inhibitors. Curr. Oncol. Rep. 2002, 4, 3746.

[90] Kortmansky, J.; Schwartz, G. K. Bryostatin-1: a novel PKC inhibitor in clinical development. Cancer Invest. 2003, 21, 924-936.

[91] Pavlick, A.C.; Wu, J.; Roberts, J.; Rosenthal, M. A.; Hamilton, A.; Wadler, S.; Farrell, K.; Carr, M.; Fry, D.; Murgo, A. J.; Oratz, R.; Hochster, H.; Liebes, L.; Muggia, F. Phase I 
Boije af Gennäs G et al. Curr Top Med Chem. 2011; 11(11): 1370-92

The final version of record is available at http://www.eurekaselect.com/88010/article

DOI: $10.2174 / 156802611795589584$

study of bryostatin 1 , a protein kinase $\mathrm{C}$ modulator, preceding cisplatin in patients with refractory non-hematologic tumors. Cancer Chemother. Pharmacol. 2009, 64, 803-810.

[92] Barr, P.M.; Lazarus, H. M.; Cooper, B. W.; Schluchter, M. D.; Panneerselvam, A.; Jacobberger, J. W.; Hsu, J. W.; Janakiraman, N.; Simic, A.; Dowlati, A.; Remick, S. C. Phase II study of bryostatin 1 and vincristine for aggressive non-Hodgkin lymphoma relapsing after an autologous stem cell transplant. Am. J. Hematol. 2009, 84, 484-487.

[93] Lam, A. P.; Sparano, J. A.; Vinciguerra, V.; Ocean, A. J.; Christos, P.; Hochster, H.; Camacho, F.; Goel, S.; Mani, S.; Kaubisch, A. Phase II study of paclitaxel plus the protein kinase $\mathrm{C}$ inhibitor bryostatin-1 in advanced pancreatic carcinoma. Am. J. Clin. Oncol. 2010, $33,121-124$.

[94] Ku, G.Y.; Ilson, D. H.; Schwartz, L. H.; Capanu, M.; O'Reilly, E.; Shah, M. A.; Kelsen, D. P.; Schwartz, G. K. Phase II trial of sequential paclitaxel and $1 \mathrm{~h}$ infusion of bryostatin-1 in patients with advanced esophageal cancer. Cancer Chemother. Pharmacol. 2008, 62, 875880.

[95] Roberts, J.D.; Smith, M. R.; Feldman, E. J.; Cragg, L.; Millenson, M. M.; Roboz, G. J.; Honeycutt, C.; Thune, R.; Padavic-Shaller, K.; Carter, W. H.; Ramakrishnan, V.; Murgo, A. J.; Grant, S. Phase I study of bryostatin 1 and fludarabine in patients with chronic lymphocytic leukemia and indolent (non-Hodgkin's) lymphoma. Clin. Cancer Res. 2006, 12, $5809-5816$.

[96] El-Rayes, B.F.; Gadgeel, S.; Shields, A. F.; Manza, S.; Lorusso, P.; Philip, P. A. Phase I study of bryostatin 1 and gemcitabine. Clin. Cancer Res. 2006, 12, 7059-7062.

[97] Peterson, A.C.; Harlin, H.; Karrison, T.; Vogelzang, N. J.; Knost, J. A.; Kugler, J. W.; Lester, E.; Vokes, E.; Gajewski, T. F.; Stadler, W. M. A randomized phase II trial of interleukin-2 in combination with four different doses of bryostatin-1 in patients with renal cell carcinoma. Invest. New Drugs 2006, 24, 141-149. 
Boije af Gennäs G et al. Curr Top Med Chem. 2011; 11(11): 1370-92

The final version of record is available at http://www.eurekaselect.com/88010/article

DOI: $10.2174 / 156802611795589584$

[98] Ajani, J.A.; Jiang, Y.; Faust, J.; Chang, B. B.; Ho, L.; Yao, J. C.; Rousey, S.; Dakhil, S.;

Cherny, R. C.; Craig, C.; Bleyer, A. A multi-center phase II study of sequential paclitaxel and bryostatin-1 (NSC 339555) in patients with untreated, advanced gastric or gastroesophageal junction adenocarcinoma. Invest. New Drugs 2006, 24, 353-357.

[99] Khan, T.K.; Nelson, T. J.; Verma, V. A.; Wender, P. A.; Alkon, D. L. A cellular model of Alzheimer's disease therapeutic efficacy: PKC activation reverses $A \beta$-induced biomarker abnormality on cultured fibroblasts. Neurobiol. Dis. 2009, 34, 332-339.

[100] Etcheberrigaray, R.; Tan, M.; Dewachter, I.; Kuiperi, C.; Van der Auwera, I.; Wera, S.;

Qiao, L.; Bank, B.; Nelson, T. J.; Kozikowski, A. P.; Van Leuven, F.; Alkon, D. Therapeutic effects of PKC activators in Alzheimer's disease transgenic mice. Proc. Natl. Acad. Sci. USA. 2004, 101, 11141-11146.

[101] US National Institutes of Health. Clinical trials.gov. http://clinicaltrials.gov/ (Accessed June 29, 2010).

[102] Pascale, A.; Amadio, M.; Quattrone, A. Defining a neuron: neuronal ELAV proteins. Cell Mol. Life Sci. 2008, 65, 128-140.

[103] Pascale, A.; Amadio, M.; Scapagnini, G.; Lanni, C.; Racchi, M.; Provenzani, A.; Govoni, S.; Alkon, D. L.; Quattrone, A. Neuronal ELAV proteins enhance mRNA stability by a PKC $\alpha$-dependent pathway. Proc. Natl. Acad. Sci. USA 2005, 102, 12065-12070.

[104] Sun, M.K.; Hongpaisan, J.; Nelson, T. J.; Alkon, D. L. Poststroke neuronal rescue and synaptogenesis mediated in vivo by protein kinase $\mathrm{C}$ in adult brains. Proc. Natl. Acad. Sci. USA 2008, 105, 13620-13625.

[105] Sun, M. K.; Hongpaisan, J.; Alkon, D. L. Postischemic PKC activation rescues retrograde and anterograde long-term memory. Proc. Natl. Acad. Sci. USA 2009, 106, 1467614680. 
Boije af Gennäs G et al. Curr Top Med Chem. 2011; 11(11): 1370-92

The final version of record is available at http://www.eurekaselect.com/88010/article

DOI: $10.2174 / 156802611795589584$

[106] Jassbi, A. R. Chemistry and biological activity of secondary metabolites in Euphorbia from Iran. Phytochemistry 2006, 67, 1977-1984.

[107] Ogbourne, S.M.; Hampson, P.; Lord, J. M.; Parsons, P.; De Witte, P.A.; Suhrbier, A. Proceedings of the first international conference on PEP005. Anticancer Drugs 2007, 18, 357-362.

[108] Hohmann, J.; Evanics, F.; Berta, L.; Bartok, T. Diterpenoids from Euphorbia peplus. Planta Med. 2000, 66, 291-294.

[109] Kedei, N.; Lundberg, D. J.; Toth, A.; Welburn, P.; Garfield, S. H.; Blumberg, P. M. Characterization of the interaction of ingenol 3-angelate with protein kinase C. Cancer Res. 2004, 64, 3243-3255.

[110] Krauter, G.; Von der Lieth, C. W.; Schmidt, R.; Hecker, E. Structure/activity relationships of polyfunctional diterpenes of the tigliane type. A pharmacophore model for protein-kinase-C activators based on structure/activity studies and molecular modeling of the tumor promoters $12-O$-tetradecanoylphorbol 13 -acetate and 3-O-tetradecanoylingenol. Eur. J. Biochem. 1996, 242, 417-427.

[111] Winkler, J. D.; Hong, B.; Bahador, A.; Kazanietz, M. G.; Blumberg, P. M. Synthesis of ingenol analogues with affinity for protein kinase C. Bioorg. Med. Chem. Lett. 1993, 3, 577580.

[112] Hampson, P.; Chahal, H.; Khanim, F.; Hayden, R.; Mulder, A.; Assi, L. K.; Bunce, C. M.; Lord, J. M. PEP005, a selective small-molecule activator of protein kinase C, has potent antileukemic activity mediated via the delta isoform of PKC. Blood 2005, 106, 1362-1368.

[113] Hampson, P.; Kavanagh, D.; Smith, E.; Wang, K.; Lord, J. M.; Ed Rainger, G. The anti-tumor agent, ingenol-3-angelate (PEP005), promotes the recruitment of cytotoxic neutrophils by activation of vascular endothelial cells in a PKC-delta dependent manner. Cancer Immunol. Immunother. 2008, 57, 1241-1251. 
Boije af Gennäs G et al. Curr Top Med Chem. 2011; 11(11): 1370-92

The final version of record is available at http://www.eurekaselect.com/88010/article

DOI: $10.2174 / 156802611795589584$

[114] Blanco-Molina, M.; Tron, G. C.; Macho, A.; Lucena, C.; Calzado, M. A.; Munoz, E.; Appendino, G. Ingenol esters induce apoptosis in Jurkat cells through an AP-1 and NF- $\mathrm{B}$ independent pathway. Chem. Biol. 2001, 8, 767-778.

[115] Zayed, S. M.; Farghaly, M.; Taha, H.; Gotta, H.; Hecker, E. Dietary cancer risk conditional cancerogens in produce of livestock fed on species of spurge (Euphorbiaceae). I. Skin irritant and tumor-promoting ingenane-type diterpene esters in E. peplus, one of several herbaceous Euphorbia species contaminating fodder of livestock. J. Cancer Res. Clin. Oncol. 1998, 124, 131-140.

[116] Gillespie, S. K.; Zhang, X. D.; Hersey, P. Ingenol 3-angelate induces dual modes of cell death and differentially regulates tumor necrosis factor-related apoptosis-inducing ligand-induced apoptosis in melanoma cells. Mol. Cancer Ther. 2004, 3, 1651-1658.

[117] Lee, W. Y.; Hampson, P.; Coulthard, L.; Ali, F.; Salmon, M.; Lord, J. M.; ScheelToellner, D. Novel anti-leukemic compound ingenol 3-angelate inhibits T cell apoptosis by activating PKC theta. J. Biol. Chem. Published online 2010 May 14.

[118] Ogbourne, S. M.; Suhrbier, A.; Jones, B.; Cozzi, S.; Boyle, G. M.; Morris, M.; McAlpine, D.; Johns, J.; Scott, T. M.; Sutherland, K. P.; Gardner, J. M.; Le, T. T.; Lenarczyk, A.; Aylward, J. H.; Parsons, P. G. Antitumor activity of 3-ingenyl angelate: plasma membrane and mitochondrial disruption and necrotic cell death. Cancer Res. 2004, 64, 28332839.

[119] Benhadji, K. A.; Serova, M.; Ghoul, A.; Cvitkovic, E.; Le Tourneau, C.; Ogbourne, S. M.; Lokiec, F.; Calvo, F.; Hammel, P.; Faivre, S.; Raymond, E. Antiproliferative activity of PEP005, a novel ingenol angelate that modulates PKC functions, alone and in combination with cytotoxic agents in human colon cancer cells. Br. J. Cancer. 2008, 99, 1808-1815.

[120] Serova, M.; Ghoul, A.; Benhadji, K. A.; Faivre, S.; Le Tourneau, C.; Cvitkovic, E.; Lokiec, F.; Lord, J.; Ogbourne, S. M.; Calvo, F.; Raymond, E. Effects of protein kinase C 
Boije af Gennäs G et al. Curr Top Med Chem. 2011; 11(11): 1370-92

The final version of record is available at http://www.eurekaselect.com/88010/article

DOI: $10.2174 / 156802611795589584$

modulation by PEP005, a novel ingenol angelate, on mitogen-activated protein kinase and phosphatidylinositol 3-kinase signaling in cancer cells. Mol. Cancer Ther. 2008, 7, 915-922.

[121] Hampson, P.; Wang, K.; Milverton, L.; Ersvaer, E.; Bruserud, O.; Lord, J. M. Kinetics of ERK1/2 activation determine sensitivity of acute myeloid leukaemia cells to the induction of apoptosis by the novel small molecule ingenol 3-angelate (PEP005). Apoptosis, Published online 2010 May 14.

[122] Cozzi, S. J.; Parsons, P. G.; Ogbourne, S. M.; Pedley, J.; Boyle, G. M. Induction of senescence in diterpene ester-treated melanoma cells via protein kinase C-dependent hyperactivation of the mitogen-activated protein kinase pathway. Cancer Res. 2006, 66, 10083-10091.

[123] Olsnes, A. M.; Ersvaer, E.; Ryningen, A.; Paulsen, K.; Hampson, P.; Lord, J. M.; Gjertsen, B. T.; Kristoffersen, E. K.; Bruserud, O. The protein kinase C agonist PEP005 increases $\mathrm{NF}-\kappa \mathrm{B}$ expression, induces differentiation and increases constitutive chemokine release by primary acute myeloid leukaemia cells. Br. J. Haematol. 2009, 145, 761-774.

[124] Mason, S. A.; Cozzi, S. J.; Pierce, C. J.; Pavey, S. J.; Parsons, P. G.; Boyle, G. M. The induction of senescence-like growth arrest by protein kinase C-activating diterpene esters in solid tumor cells. Invest. New Drugs, Published online 2009 July 28.

[125] Ersvaer, E.; Hampson, P.; Hatfield, K.; Ulvestad, E.; Wendelbo, O.; Lord, J. M.; Gjertsen, B. T.; Bruserud, O. T cells remaining after intensive chemotherapy for acute myelogenous leukemia show a broad cytokine release profile including high levels of interferon- $\gamma$ that can be further increased by a novel protein kinase $\mathrm{C}$ agonist PEP005. Cancer Immunol. Immunother. 2007, 56, 913-925.

[126] Challacombe, J. M.; Suhrbier, A.; Parsons, P. G.; Jones, B.; Hampson, P.; Kavanagh, D.; Rainger, G. E.; Morris, M.; Lord, J. M.; Le, T. T. T.; Hoang-Le, D.; Ogbourne, S. M. 
Boije af Gennäs G et al. Curr Top Med Chem. 2011; 11(11): 1370-92

The final version of record is available at http://www.eurekaselect.com/88010/article

DOI: $10.2174 / 156802611795589584$

Neutrophils are a key component of the antitumor efficacy of topical chemotherapy with ingenol-3-angelate. J. Immunol. 2006, 177, 8123-8132.

[127] Le, T. T.; Gardner, J.; Hoang-Le, D.; Schmidt, C. W.; MacDonald, K. P.; Lambley, E.; Schroder, W. A.; Ogbourne, S. M.; Suhrbier, A. Immunostimulatory cancer chemotherapy using local ingenol-3-angelate and synergy with immunotherapies. Vaccine 2009, 27, 30533062.

[128] Siller, G.; Gebauer, K.; Welburn, P.; Katsamas, J.; Ogbourne, S. M. PEP005 (ingenol mebutate) gel, a novel agent for the treatment of actinic keratosis: results of a randomized, double-blind, vehicle-controlled, multicentre, phase IIa study. Australas. J. Dermatol. 2009, $50,16-22$.

[129] Anderson, L.; Schmieder, G. J.; Werschler, W. P.; Tschen, E. H.; Ling, M. R.; Stough, D. B.; Katsamas, J. Randomized, double-blind, double-dummy, vehicle-controlled study of ingenol mebutate gel $0.025 \%$ and $0.05 \%$ for actinic keratosis. J. Am. Acad. Dermatol. 2009, 60, 934-943.

[130] Takashima, M.; Sakai, H. A new toxic substance, teleocidin produced by Streptomyces. Part I. Production, isolation, and chemical studies. Bull. Agric. Chem. Soc. Jpn. 1960, 24, 647-651.

[131] Fujiki, H.; Mori, M.; Nakayasu, M.; Terada, M.; Sugimura, T.; Moore, R. E. Indole alkaloids: dihydroteleocidin B, teleocidin, and lyngbyatoxin A as members of a new class of tumor promoters. Proc. Natl. Acad. Sci. USA 1981, 78, 3872-3876.

[132] Umezawa, K.; Weinstein, I. B.; Horowitz, A.; Fujiki, H.; Matsushima, T.; Sugimura, T. Similarity of teleocidin B and phorbol ester tumour promoters in effects on membrane receptors. Nature 1981, 290, 411-413.

[133] Irie, K.; Nakagawa, Y.; Ohigashi, H. Toward the development of new medicinal leads with selectivity for protein kinase C isozymes. Chem. Rec. 2005, 5, 185-195. 
Boije af Gennäs G et al. Curr Top Med Chem. 2011; 11(11): 1370-92

The final version of record is available at http://www.eurekaselect.com/88010/article

DOI: $10.2174 / 156802611795589584$

[134] Kozikowski, A. P.; Chen, Y.; Subhasish, T.; Lewin, N. E.; Blumberg, P. M.; Zhong, Z.;

D'Annibale, M. A.; Wang, W.; Shen, Y.; Langley, B. Searching for disease modifiers-PKC activation and HDAC inhibition - a dual drug approach to Alzheimer's disease that decreases A $\beta$ production while blocking oxidative stress. ChemMedChem. 2009, 4, 1095-1105.

[135] Endo, Y.; Takehana, S.; Ohno, M.; Driedger, P. E.; Stabel, S.; Mizutani, M. Y.; Tomioka, N.; Itai, A.; Shudo, K. Clarification of the binding mode of teleocidin and benzolactams to the Cys 2 domain of protein kinase $\mathrm{C} \delta$ by synthesis of hydrophobically modified, teleocidin-mimicking benzolactams and computational docking simulation. J. Med. Chem. 1998, 41, 1476-1496.

[136] Rong, S. B.; Enyedy, I. J.; Qiao, L.; Zhao, L.; Ma, D.; Pearce, L. L.; Lorenzo, P. S.; Stone, J. C.; Blumberg, P. M.; Wang, S.; Kozikowski, A. P. Structural basis of RasGRP binding to high-affinity PKC ligands. J. Med. Chem. 2002, 45, 853-860.

[137] Kozikowski, A. P.; Nowak, I.; Petukhov, P. A.; Etcheberrigaray, R.; Mohamed, A.; Tan, M.; Lewin, N.; Hennings, H.; Pearce, L. L.; Blumberg, P. New amide-bearing benzolactam-based protein kinase $\mathrm{C}$ modulators induce enhanced secretion of the amyloid precursor protein metabolite sAPPa. J. Med. Chem. 2003, 46, 364-373.

[138] Yanagita, R. C.; Nakagawa, Y.; Yamanaka, N.; Kashiwagi, K.; Saito, N.; Irie, K. Synthesis, conformational analysis, and biological evaluation of 1-hexylindolactam-V10 as a selective activator for novel protein kinase C isozymes. J. Med. Chem. 2008, 51, 46-56.

[139] Nakagawa, Y.; Irie, K.; Nakamura, Y.; Ohigashi, H. The amide hydrogen of (-)indolactam- $\mathrm{V}$ and benzolactam-V8's plays a critical role in protein kinase $\mathrm{C}$ binding and tumor-promoting activities. Bioorg. Med. Chem. Lett. 2001, 11, 723-728.

[140] Nakagawa, Y.; Irie, K.; Yanagita, R. C.; Ohigashi, H.; Tsuda, K. Indolactam-V is involved in the $\mathrm{CH} /$ pi interaction with Pro-11 of the $\mathrm{PKC} \delta \mathrm{C} 1 \mathrm{~B}$ domain: application for the structural optimization of the PKC $\delta$ ligand. J. Am. Chem. Soc. 2005, 127, 5746-5747. 
Boije af Gennäs G et al. Curr Top Med Chem. 2011; 11(11): 1370-92

The final version of record is available at http://www.eurekaselect.com/88010/article

DOI: $10.2174 / 156802611795589584$

[141] Irie, K.; Nakagawa, Y.; Ohigashi, H. Indolactam and benzolactam compounds as new medicinal leads with binding selectivity for $\mathrm{C} 1$ domains of protein kinase $\mathrm{C}$ isozymes. Curr. Pharm. Des. 2004, 10, 1371-1385.

[142] Mach, U.R.; Lewin, N. E.; Blumberg, P. M.; Kozikowski, A. P. Synthesis and pharmacological evaluation of 8 - and 9-substituted benzolactam-V8 derivatives as potent ligands for protein kinase $\mathrm{C}$, a therapeutic target for Alzheimer's disease. ChemMedChem. 2006, $1,307-314$.

[143] Ma, D.; Zhang, T.; Wang, G.; Kozikowski, A. P.; Lewin, N. E.; Blumberg, P. M. Synthesis of 7,8-disubstituted benzolactam-V8 and its binding to protein kinase C. Bioorg. Med. Chem. Lett. 2001, 11, 99-101.

[144] Ma, D.; Tang, G.; Kozikowski, A. P. Synthesis of 7-substituted benzolactam-V8s and their selectivity for protein kinase C isozymes. Org. Lett. 2002, 4, 2377-2380.

[145] Ma, D.; Tang, W.; Kozikowski, A. P.; Lewin, N. E.; Blumberg, P. M. General and Stereospecific route to 9-substituted, 8,9-disubstituted, and 9,10-disubstituted analogues of benzolactam-V8. J. Org. Chem. 1999, 64, 6366-6373.

[146] Endo, Y.; Yamaguchi, M.; Hirano, M.; Shudo, K. Role of the hydrophobic moiety of tumor promoters. Synthesis and activity of 9-alkylated benzolactams. Chem. Pharm. Bull. 1996, 44, 1138-1140.

[147] Endo, Y.; Ohno, M.; Hirano, M.; Itai, A.; Shudo, K. Synthesis, conformation, and biological activity of teleocidin mimics, benzolactams. A clarification of the conformational flexibility problem in structure-activity studies of teleocidins. J. Am. Chem. Soc. 1996, 118, $1841-1855$

[148] Endo, Y.; Yokoyama, A. Role of the hydrophobic moiety of tumor promoters. Synthesis and activity of 2-alkylated benzolactams. Bioorg. Med. Chem. Lett. 2000, 10, 6366. 
Boije af Gennäs G et al. Curr Top Med Chem. 2011; 11(11): 1370-92

The final version of record is available at http://www.eurekaselect.com/88010/article

DOI: $10.2174 / 156802611795589584$

[149] Kozikowski, A. P.; Ma, D.; Pang, Y.; Shum, P.; Likic, V.; Mishra, P. K.; Macura, S.; Basu, A.; Lazo, J. S.; Ball, R. G. Synthesis, molecular modeling, 2-D NMR, and biological evaluation of ILV mimics as potential modulators of protein kinase C. J. Am. Chem. Soc. 1993, 115, 3957-3965.

[150] Ma, D.; Wang, G.; Wang, S.; Kozikowski, A. P.; Lewin, N. E.; Blumberg, P. M. Synthesis and protein kinase $\mathrm{C}$ binding activity of benzolactam-V7. Bioorg. Med. Chem. Lett. 1999, 9, 1371-1374.

[151] Sridhar, J.; Wei, Z. L.; Nowak, I.; Lewin, N. E.; Ayres, J. A.; Pearce, L. V.; Blumberg, P. M.; Kozikowski, A. P. New bivalent PKC ligands linked by a carbon spacer: enhancement in binding affinity. J. Med. Chem. 2003, 46, 4196-4204.

[152] Kozikowski, A. P.; Wang, S.; Ma, D.; Yao, J.; Ahmad, S.; Glazer, R. I.; Bogi, K.; Acs, P.; Modarres, S.; Lewin, N. E.; Blumberg, P. M. Modeling, chemistry, and biology of the benzolactam analogues of indolactam V (ILV). 2. Identification of the binding site of the benzolactams in the CRD2 activator-binding domain of $\mathrm{PKC} \delta$ and discovery of an ILV analogue of improved isozyme selectivity. J. Med. Chem. 1997,40, 1316-1326.

[153] Nakagawa, Y.; Irie, K.; Yanagita, R. C.; Ohigashi, H.; Tsuda, K.; Kashiwagi, K.; Saito, N. Design and synthesis of 8-octyl-benzolactam-V9, a selective activator for protein kinase C $\varepsilon$ and $\eta . J$. Med. Chem. 2006, 49, 2681-2688.

[154] Nakagawa, Y.; Irie, K.; Masuda, A.; Ohigashi, H. Synthesis, conformation and PKC isozyme surrogate binding of new lactone analogues of benzolactame-V8s. Tetrahedron 2002, 58, 2101-2115.

[155] Bhagavan, S.; Ibarreta, D.; Ma, D.; Kozikowski, A. P.; Etcheberrigaray, R. Restoration of TEA-induced calcium responses in fibroblasts from Alzheimer's disease patients by a PKC activator. Neurobiol. Dis. 1998, 5, 177-187. 
Boije af Gennäs G et al. Curr Top Med Chem. 2011; 11(11): 1370-92

The final version of record is available at http://www.eurekaselect.com/88010/article

DOI: $10.2174 / 156802611795589584$

[156] Ibarreta, D.; Duchen, M.; Ma, D.; Qiao, L.; Kozikowski, A. P.; Etcheberrigaray, R. Benzolactam (BL) enhances sAPP secretion in fibroblasts and in PC12 cells. Neuroreport 1999, 10, 1035-1040.

[157] Yang, H.; Pan, J.; Ba, M.; Sun, Z.; Ma, G.; Lu, G.; Xiao, Q. C.,S. New protein kinase C activator regulates amyloid precursor protein processing in vitro by increasing $\alpha$-secretase activity. Eur. J. Neurosci. 2007, 26, 381-391.

[158] Chen, S.; Borowiak, M.; Fox, J. L.; Maehr, R.; Osafune, K.; Davidow, L.; Lam, K.; Peng, L. F.; Schreiber, S. L.; Rubin, L. L.; Melton, D. A small molecule that directs differentiation of human ESCs into the pancreatic lineage. Nat. Chem. Biol. 2009, 5, 258-265. [159] Marquez, V. E.; Blumberg, P. M. Synthetic diacylglycerols (DAG) and DAG-lactones as activators of protein kinase C (PK-C). Acc. Chem. Res. 2003, 36, 434-443.

[160] Kang, J. H.; Siddiqui, M. A.; Sigano, D. M.; Krajewski, K.; Lewin, N. E.; Pu, Y.; Blumberg, P. M.; Lee, J.; Marquez, V. E. Conformationally constrained analogues of diacylglycerol. 24. Asymmetric synthesis of a chiral (R)-DAG-lactone template as a versatile precursor for highly functionalized DAG-lactones. Org. Lett. 2004, 6, 2413-2416.

[161] Duan, D.; Lewin, N. E.; Sigano, D. M.; Blumberg, P. M.; Marquez, V. E. Conformationally constrained analogues of diacylglycerol. 21. A solid-phase method of synthesis of diacylglycerol lactones as a prelude to a combinatorial approach for the synthesis of protein kinase C isozyme-specific ligands. J. Med. Chem. 2004, 47, 3248-3254.

[162] Kang, J. H.; Peach, M. L.; Pu, Y.; Lewin, N. E.; Nicklaus, M. C.; Blumberg, P. M.; Marquez, V. E. Conformationally constrained analogues of diacylglycerol (DAG). 25. Exploration of the sn-1 and sn-2 carbonyl functionality reveals the essential role of the sn-1 carbonyl at the lipid interface in the binding of DAG-lactones to protein kinase C. J. Med. Chem. 2005, 48, 5738-5748. 
Boije af Gennäs G et al. Curr Top Med Chem. 2011; 11(11): 1370-92

The final version of record is available at http://www.eurekaselect.com/88010/article

DOI: $10.2174 / 156802611795589584$

[163] Nacro, K.; Bienfait, B.; Lee, J.; Han, K. C.; Kang, J. H.; Benzaria, S.; Lewin, N. E.; Bhattacharyya, D. K.; Blumberg, P. M.; Marquez, V. E. Conformationally constrained analogues of diacylglycerol (DAG). 16. How much structural complexity is necessary for recognition and high binding affinity to protein kinase C? J. Med. Chem. 2000, 43, 921-944. [164] Kang, J. H.; Benzaria, S.; Sigano, D. M.; Lewin, N. E.; Pu, Y.; Peach, M. L.; Blumberg, P. M.; Marquez, V. E. Conformationally constrained analogues of diacylglycerol. 26. Exploring the chemical space surrounding the $\mathrm{C} 1$ domain of protein kinase $\mathrm{C}$ with $\mathrm{DAG}$ lactones containing aryl groups at the sn-1 and sn-2 positions. J. Med. Chem. 2006, 49, 31853203.

[165] Comin, M. J.; Czifra, G.; Kedei, N.; Telek, A.; Lewin, N. E.; Kolusheva, S.; Velasquez, J. F.; Kobylarz, R.; Jelinek, R.; Blumberg, P. M.; Marquez, V. E. Conformationally constrained analogues of diacylglycerol (DAG). 31. Modulation of the biological properties of diacylgycerol lactones (DAG-lactones) containing rigid-rod acyl groups separated from the core lactone by spacer units of different lengths. J. Med. Chem. 2009, 52, 3274-3283.

[166] Malolanarasimhan, K.; Kedei, N.; Sigano, D. M.; Kelley, J. A.; Lai, C. C.; Lewin, N. E.; Surawski, R. J.; Pavlyukovets, V. A.; Garfield, S. H.; Wincovitch, S.; Blumberg, P. M.; Marquez, V. E. Conformationally constrained analogues of diacylglycerol (DAG). 27. modulation of membrane translocation of protein kinase $\mathrm{C}$ (PKC) Isozymes $\alpha$ and $\delta$ by diacylglycerol lactones (DAG-lactones) containing rigid-rod acyl groups. J. Med. Chem. 2007, 50, 962-978.

[167] Nacro, K.; Lee, J.; Barchi, J. J.; Lewin, N. E.; Blumberg, P. M.; Marquez, V. E. Conformationally constrained analogues of diacylglycerol (DAG). Part 19: Asymmetric syntheses of (3R)- and (3S)-3-hydroxy-4,4-disubstituted heptono-1,4-lactones as protein kinase C (PK-C) with increased hydrophilicity. Tetrahedron 2002, 58, 5335-5345. 
Boije af Gennäs G et al. Curr Top Med Chem. 2011; 11(11): 1370-92

The final version of record is available at http://www.eurekaselect.com/88010/article

DOI: $10.2174 / 156802611795589584$

[168] Tamamura, H.; Sigano, D. M.; Lewin, N. E.; Peach, M. L.; Nicklaus, M. C.; Blumberg, P. M.; Marquez, V. E. Conformationally constrained analogues of diacylglycerol (DAG). 23. Hydrophobic ligand-protein interactions versus ligand-lipid interactions of DAG-lactones with protein kinase C (PK-C). J. Med. Chem. 2004, 47, 4858-4864.

[169] Baba, Y.; Ogoshi, Y.; Hirai, G.; Yanagisawa, T.; Nagamatsu, K.; Mayumi, S.; Hashimoto, Y.; Sodeoka, M. Design, synthesis, and structure-activity relationship of new isobenzofuranone ligands of protein kinase C. Bioorg. Med. Chem. Lett. 2004, 14, 29632967.

[170] Choi, Y.; Pu, Y.; Peach, M. L.; Kang, J. H.; Lewin, N. E.; Sigano, D. M.; Garfield, S. H.; Blumberg, P. M.; Marquez, V. E. Conformationally constrained analogues of diacylglycerol (DAG). 28. DAG-dioxolanones reveal a new additional interaction site in the C1b domain of PKC $\delta . J . M e d$. Chem. 2007, 50, 3465-3481.

[171] Lee, J.; Han, K. C.; Kang, J. H.; Pearce, L. L.; Lewin, N. E.; Yan, S.; Benzaria, S.; Nicklaus, M. C.; Blumberg, P. M.; Marquez, V. E. Conformationally constrained analogues of diacylglycerol. 18. The incorporation of a hydroxamate moiety into diacylglycerollactones reduces lipophilicity and helps discriminate between sn-1 and sn- 2 binding modes to protein kinase C (PK-C). Implications for isozyme specificity. J. Med. Chem. 2001, 44, 43094312, and erratum J. Med. Chem. 2003, 46, 2794.

[172] Tamamura, H.; Sigano, D. M.; Lewin, N. E.; Blumberg, P. M.; Marquez, V. E. Conformationally constrained analogues of diacylglycerol. 20. The search for an elusive binding site on protein kinase $\mathrm{C}$ through relocation of the carbonyl pharmacophore along the sn-1 side chain of 1,2-diacylglycerol lactones. J. Med. Chem. 2004, 47, 644-655.

[173] Kang, J. H.; Kim, S. Y.; Lee, J.; Marquez, V. E.; Lewin, N. E.; Pearce, L. V.; Blumberg, P. M. Macrocyclic diacylglycerol-bis-lactones as conformationally constrained 
Boije af Gennäs G et al. Curr Top Med Chem. 2011; 11(11): 1370-92

The final version of record is available at http://www.eurekaselect.com/88010/article

DOI: $10.2174 / 156802611795589584$

analogues of diacylglycerol-lactones. Interactions with protein kinase C. J. Med. Chem. 2004, 47, 4000-4007.

[174] Pu, Y.; Perry, N. A.; Yang, D.; Lewin, N. E.; Kedei, N.; Braun, D. C.; Choi, S. H.;

Blumberg, P. M.; Garfield, S. H.; Stone, J. C.; Duan, D.; Marquez, V. E. A novel diacylglycerol-lactone shows marked selectivity in vitro among $\mathrm{C} 1$ domains of protein kinase $\mathrm{C}$ (PKC) isoforms $\alpha$ and $\delta$ as well as selectivity for RasGRP compared with PKC $\alpha . J$. Biol. Chem. 2005, 280, 27329-27338.

[175] Duan, D.; Sigano, D. M.; Kelley, J. A.; Lai, C. C.; Lewin, N. E.; Kedei, N.; Peach, M. L.; Lee, J.; Abeyweera, T. P.; Rotenberg, S. A.; Kim, H.; Kim, Y. H.; El Kazzouli, S.; Chung, J. U.; Young, H. A.; Young, M. R.; Baker, A.; Colburn, N. H.; Haimovitz-Friedman, A.; Truman, J. P.; Parrish, D. A.; Deschamps, J. R.; Perry, N. A.; Surawski, R. J.; Blumberg, P. M.; Marquez, V. E. Conformationally constrained analogues of diacylglycerol. 29. Cells sort diacylglycerol-lactone chemical zip codes to produce diverse and selective biological activities. J. Med. Chem. 2008, 51, 5198-5220.

[176] El Kazzouli, S.; Lewin, N. E.; Blumberg, P. M.; Marquez, V. E. Conformationally constrained analogues of diacylglycerol. 30. An investigation of diacylglycerol-lactones containing heteroaryl groups reveals compounds with high selectivity for Ras guanyl nucleotide-releasing proteins. J. Med. Chem. 2008, 51, 5371-5386.

[177] Garcia-Bermejo, M. L.; Leskow, F. C.; Fujii, T.; Wang, Q.; Blumberg, P. M.; Ohba, M.; Kuroki, T.; Han, K. C.; Lee, J.; Marquez, V. E.; Kazanietz, M. G. Diacylglycerol (DAG)lactones, a new class of protein kinase $\mathrm{C}$ (PKC) agonists, induce apoptosis in LNCaP prostate cancer cells by selective activation of PKC $\alpha$. J. Biol. Chem. 2002, 277, 645-655, and erratum J. Biol. Chem. 2004, 279, 23846

[178] Truman, J. P.; Rotenberg, S. A.; Kang, J. H.; Lerman, G.; Fuks, Z.; Kolesnick, R.; Marquez, V. E.; Haimovitz-Friedman, A. PKC $\alpha$ activation downregulates ATM and radio- 
Boije af Gennäs G et al. Curr Top Med Chem. 2011; 11(11): 1370-92

The final version of record is available at http://www.eurekaselect.com/88010/article

DOI: $10.2174 / 156802611795589584$

sensitizes androgen-sensitive human prostate cancer cells in vitro and in vivo. Cancer. Biol.

Ther. 2009, 8, 54-63.

[179] Kang, J. H.; Kim, Y.; Won, S. H.; Park, S. K.; Lee, C. W.; Kim, H. M.; Lewin, N. E.;

Perry, N. A.; Pearce, L. V.; Lundberg, D. J.; Surawski, R. J.; Blumberg, P. M.; Lee, J. Polar 3-alkylidene-5-pivaloyloxymethyl-5'-hydroxymethyl-gamma-lactones as protein kinase C ligands and antitumor agents. Bioorg. Med. Chem. Lett. 2010, 20, 1008-1012.

[180] Lee, J.; Kang, J. H.; Han, K. C.; Kim, Y.; Kim, S. Y.; Youn, H. S.; Mook-Jung, I.; Kim, H.; Lo Han, J. H.; Ha, H. J.; Kim, Y. H.; Marquez, V. E.; Lewin, N. E.; Pearce, L. V.; Lundberg, D. J.; Blumberg, P. M. Branched diacylglycerol-lactones as potent protein kinase C ligands and $\alpha$-secretase activators. J. Med. Chem. 2006, 49, 2028-2036.

[181] Sigano, D. M.; Peach, M. L.; Nacro, K.; Choi, Y.; Lewin, N. E.; Nicklaus, M. C.; Blumberg, P. M.; Marquez, V. E. Differential binding modes of diacylglycerol (DAG) and DAG lactones to protein kinase C (PK-C). J. Med. Chem. 2003, 46, 1571-1579.

[182] Hamer, D. H.; Bocklandt, S.; McHugh, L.; Chun, T. W.; Blumberg, P. M.; Sigano, D. M.; Marquez, V. E. Rational design of drugs that induce human immunodeficiency virus replication. J. Virol. 2003, 77, 10227-10236.

[183] Raifman, O.; Kolusheva, S.; Comin, M. J.; Kedei, N.; Lewin, N. E.; Blumberg, P. M.; Marquez, V. E.; Jelinek, R. Membrane anchoring of diacylglycerol lactones substituted with rigid hydrophobic acyl domains correlates with biological activities. FEBS J. 2010, 277, 233243.

[184] Arcamone, F.; Cassinelli, G.; Fantini, G.; Grein, A.; Orezzi, P.; Pol, C.; Spalla, C. Adriamycin, 14-hydroxydaunomycin, a new antitumor antibiotic from S. peucetius var. caesius. Biotechnol. Bioeng. 1969, 11, 1101-1110. 
Boije af Gennäs G et al. Curr Top Med Chem. 2011; 11(11): 1370-92

The final version of record is available at http://www.eurekaselect.com/88010/article

DOI: $10.2174 / 156802611795589584$

[185] Minotti, G.; Menna, P.; Salvatorelli, E.; Cairo, G.; Gianni, L. Anthracyclines: molecular advances and pharmacologic developments in antitumor activity and cardiotoxicity. Pharmacol. Rev. 2004, 56, 185-229.

[186] Frederick, C. A.; Williams, L. D.; Ughetto, G.; van der Marel, G. A.; van Boom, J. H.; Rich, A.; Wang, A. H. Structural comparison of anticancer drug-DNA complexes: adriamycin and daunomycin. Biochemistry 1990, 29, 2538-2549.

[187] Israel, M.; Seshadri, R.; Idriss, J. M. N-Benzyladriamycin-14-valerate (AD198), a promising new adriamycin (ADR) analog. Proc. Am. Assoc. Cancer Res. 1985, 26, 220.

[188] Roaten, J. B.; Kazanietz, M. G.; Sweatman, T. W.; Lothstein, L.; Israel, M.; Parrill, A. L. Molecular models of $N$-benzyladriamycin-14-valerate (AD 198) in complex with the phorbol ester-binding C1b domain of protein kinase C-delta. J. Med. Chem. 2001, 44, 10281034.

[189] Lothstein, L.; Israel, M.; Sweatman, T. W. Anthracycline drug targeting: cytoplasmic versus nuclear--a fork in the road. Drug Resist. Updat. 2001, 4, 169-177.

[190] Roaten, J. B.; Kazanietz, M. G.; Caloca, M. J.; Bertics, P. J.; Lothstein, L.; Parrill, A. L.; Israel, M.; Sweatman, T. W. Interaction of the novel anthracycline antitumor agent Nbenzyladriamycin-14-valerate with the $\mathrm{C} 1$-regulatory domain of protein kinase $\mathrm{C}$ : structural requirements, isoform specificity, and correlation with drug cytotoxicity. Mol. Cancer. Ther. 2002, 1, 483-492.

[191] Barrett, C. M.; Lewis, F. L.; Roaten, J. B.; Sweatman, T. W.; Israel, M.; Cleveland, J. L.; Lothstein, L. Novel extranuclear-targeted anthracyclines override the antiapoptotic functions of Bcl-2 and target protein kinase $\mathrm{C}$ pathways to induce apoptosis. Mol. Cancer. Ther. 2002, 1, 469-481.

[192] Harstrick, A.; Vanhoefer, U.; Schleucher, N.; Schroeder, J.; Baumgart, J.; Scheulen, M. E.; Wilke, H.; Seeber, S. Activity of $N$-benzyl-adriamycin-14-valerate (AD198), a new 
Boije af Gennäs G et al. Curr Top Med Chem. 2011; 11(11): 1370-92

The final version of record is available at http://www.eurekaselect.com/88010/article

DOI: $10.2174 / 156802611795589584$

anthracycline derivate, in multidrug resistant human ovarian and breast carcinoma cell lines. Anticancer Drugs 1995, 6, 681-685.

[193] Traganos, F.; Israel, M.; Silber, R.; Seshadri, R.; Kirschenbaum, S.; Potmesil, M. Effects of new $\mathrm{N}$-alkyl analogues of adriamycin on in vitro survival and cell cycle progression of L1210 cells. Cancer Res. 1985, 45, 6273-6279.

[194] Lothstein, L.; Savranskaya, L.; Sweatman, T. W. N-Benzyladriamycin-14-valerate (AD 198) cytotoxicty circumvents Bcr-Abl anti-apoptotic signaling in human leukemia cells and also potentiates imatinib cytotoxicity. Leuk. Res. 2007, 31, 1085-1095.

[195] He, Y.; Liu, J.; Durrant, D.; Yang, H. S.; Sweatman, T.; Lothstein, L.; Lee, R. M. Nbenzyladriamycin-14-valerate (AD198) induces apoptosis through protein kinase C- $\delta$ induced phosphorylation of phospholipid scramblase 3. Cancer Res. 2005, 65, 10016-10023.

[196] Ganapathi, R.; Grabowski, D.; Sweatman, T. W.; Seshadri, R.; Israel, M. Nbenzyladriamycin-14-valerate versus progressively doxorubicin-resistant murine tumours: cellular pharmacology and characterisation of cross-resistance in vitro and in vivo. $B r . J$. Cancer 1989, 60, 819-826.

[197] Sweatman, T. W.; Seshadri, R.; Israel, M. Pharmacology of N-benzyladriamycin-14valerate in the rat. Cancer Chemother. Pharmacol. 1999, 43, 419-426.

[198] He, Y.; Liu, J.; Grossman, D.; Durrant, D.; Sweatman, T.; Lothstein, L.; Epand, R. F.; Epand, R. M.; Lee, R. M. Phosphorylation of mitochondrial phospholipid scramblase 3 by protein kinase $\mathrm{C}-\delta$ induces its activation and facilitates mitochondrial targeting of tBid. $J$. Cell. Biochem. 2007, 101, 1210-1221.

[199] Hofmann, P. A.; Israel, M.; Koseki, Y.; Laskin, J.; Gray, J.; Janik, A.; Sweatman, T. W.; Lothstein, L. N-Benzyladriamycin-14-valerate (AD 198): a non-cardiotoxic anthracycline that is cardioprotective through PKC-E activation. J. Pharmacol. Exp. Ther. 2007, 323, 658-664. 
Boije af Gennäs G et al. Curr Top Med Chem. 2011; 11(11): 1370-92

The final version of record is available at http://www.eurekaselect.com/88010/article

DOI: $10.2174 / 156802611795589584$

[200] Kashfi, K.; Israel, M.; Sweatman, T. W.; Seshadri, R.; Cook, G. A. Inhibition of mitochondrial carnitine palmitoyltransferases by adriamycin and adriamycin analogues. Biochem. Pharmacol. 1990, 40, 1441-1448.

[201] Lameh, J.; Chuang, L. F.; Israel, M.; Chuang, R. Y. Mechanistic studies on Nbenzyladriamycin-14-valerate (AD 198), a highly lipophilic alkyl adriamycin analog. Anticancer Res. 1988, 8, 689-693.

[202] Chuang, L. F.; Kung, H. F.; Israel, M.; Chuang, R. Y. Activation of human leukemia protein kinase $\mathrm{C}$ by tumor promoters and its inhibition by $\mathrm{N}$-trifluoroacetyladriamycin-14valerate (AD 32). Biochem. Pharmacol. 1992, 43, 865-872.

[203] Markman, M.; Homesley, H.; Norberts, D. A.; Schink, J.; Abbas, F.; Miller, A.; Soper, J.; Teng, N.; Hammond, N.; Muggia, F.; Israel, M.; Sweatman, T. Phase 1 trial of intraperitoneal AD-32 in gynecologic malignancies. Gynecol. Oncol. 1996, 61, 90-93.

[204] Iida, T.; Kobayashi, E.; Yoshida, M.; Sano, H. Calphostins, novel and specific inhibitors of protein kinase C. II. Chemical structures. J. Antibiot. (Tokyo) 1989, 42, 14751481.

[205] Kobayashi, E.; Nakano, H.; Morimoto, M.; Tamaoki, T. Calphostin C (UCN-1028C), a novel microbial compound, is a highly potent and specific inhibitor of protein kinase C. Biochem. Biophys. Res. Commun. 1989, 159, 548-553.

[206] Rotenberg, S. A.; Huang, M. H.; Zhu, J.; Su, L.; Riedel, H. Deletion analysis of protein kinase C inactivation by calphostin C. Mol. Carcinog. 1995, 12, 42-49.

[207] Bruns, R. F.; Miller, F. D.; Merriman, R. L.; Howbert, J. J.; Heath, W. F.; Kobayashi, E.; Takahashi, I.; Tamaoki, T.; Nakano, H. Inhibition of protein kinase $\mathrm{C}$ by calphostin $\mathrm{C}$ is light-dependent. Biochem. Biophys. Res. Commun. 1991, 176, 288-293.

[208] Gopalakrishna, R.; Chen, Z. H.; Gundimeda, U. Irreversible oxidative inactivation of protein kinase C by photosensitive inhibitor calphostin C. FEBS Lett. 1992, 314, 149-154. 
Boije af Gennäs G et al. Curr Top Med Chem. 2011; 11(11): 1370-92

The final version of record is available at http://www.eurekaselect.com/88010/article

DOI: $10.2174 / 156802611795589584$

[209] Redman, C.; Lefevre, J.; MacDonald, M. L. Inhibition of diacylglycerol kinase by the antitumor agent calphostin C. Evidence for similarity between the active site of diacylglycerol kinase and the regulatory site of protein kinase C. Biochem. Pharmacol. 1995, $50,235-241$.

[210] Areces, L. B.; Kazanietz, M. G.; Blumberg, P. M. Close similarity of baculovirusexpressed $n$-chimaerin and protein kinase $\mathrm{C} \alpha$ as phorbol ester receptors. J. Biol. Chem. 1994, 269, 19553-19558.

[211] Kazanietz, M. G.; Lewin, N. E.; Bruns, J. D.; Blumberg, P. M. Characterization of the cysteine-rich region of the Caenorhabditis elegans protein Unc-13 as a high affinity phorbol ester receptor. Analysis of ligand-binding interactions, lipid cofactor requirements, and inhibitor sensitivity. J. Biol. Chem. 1995, 270, 10777-10783.

[212] Merlic, C. A.; Aldrich, C. C.; Albaneze-Walker, J.; Saghatelian, A. Carbene Complexes in the Synthesis of Complex Natural Products: Total Synthesis of the Calphostins. J. Am. Chem. Soc. 2000, 122, 3224-3225.

[213] Merlic, C. A.; Aldrich, C. C.; Albaneze-Walker, J.; Saghatelian, A.; Mammen, J. Total synthesis of the calphostins: application of fischer carbene complexes and thermodynamic control of atropisomers. J. Org. Chem. 2001, 66, 1297-1309.

[214] Morgan, B. J.; Dey, S.; Johnson, S. W.; Kozlowski, M. C. Design, synthesis, and investigation of protein kinase $\mathrm{C}$ inhibitors: total syntheses of (+)-calphostin $\mathrm{D},(+)-$ phleichrome, cercosporin, and new photoactive perylenequinones. J. Am. Chem. Soc. 2009, $131,9413-9425$.

[215] Kobayashi, E.; Ando, K.; Nakano, H.; Iida, T.; Ohno, H.; Morimoto, M.; Tamaoki, T. Calphostins (UCN-1028), novel and specific inhibitors of protein kinase C. I. Fermentation, isolation, physico-chemical properties and biological activities. J. Antibiot. (Tokyo) 1989, 42, $1470-1474$. 
Boije af Gennäs G et al. Curr Top Med Chem. 2011; 11(11): 1370-92

The final version of record is available at http://www.eurekaselect.com/88010/article

DOI: $10.2174 / 156802611795589584$

[216] Chiarini, A.; Whitfield, J. F.; Pacchiana, R.; Armato, U.; Dal Pra, I. Photoexcited calphostin C selectively destroys nuclear lamin B1 in neoplastic human and rat cells - a novel mechanism of action of a photodynamic tumor therapy agent. Biochim. Biophys. Acta 2008, $1783,1642-1653$.

[217] Dubauskas, Z.; Beck, T. P.; Chmura, S. J.; Kovar, D. A.; Kadkhodaian, M. M.; Shrivastav, M.; Chung, T.; Stadler, W. M.; Rinker-Schaeffer, C. W. Activated calphostin C cytotoxicity is independent of p53 status and in vivo metastatic potential. Clin. Cancer Res. 1998, 4, 2391-2398.

[218] Pollack, I. F.; Kawecki, S. The effect of calphostin C, a potent photodependent protein kinase C inhibitor, on the proliferation of glioma cells in vitro. J. Neurooncol. 1997, 31, 255266.

[219] Guo, B.; Hembruff, S. L.; Villeneuve, D. J.; Kirwan, A. F.; Parissenti, A. M. Potent killing of paclitaxel- and doxorubicin-resistant breast cancer cells by calphostin C accompanied by cytoplasmic vacuolization. Breast Cancer Res. Treat. 2003, 82, 125-141.

[220] Kaul, A.; Maltese, W. A. Killing of cancer cells by the photoactivatable protein kinase $\mathrm{C}$ inhibitor, calphostin $\mathrm{C}$, involves induction of endoplasmic reticulum stress. Neoplasia 2009, 11, 823-834.

[221] Alonso, M.; Muniz, M.; Hall, C.; Velasco, A.; Hidalgo, J. Calphostin C induces selective disassembly of the Golgi complex by a protein kinase C-independent mechanism. Eur. J. Cell Biol. 1998, 76, 93-101.

[222] Morgado-Diaz, J. A.; Montesano, G.; De Souza Fernandes, S.; Redondo, P. A.; Fernandes de Souza, W.; Albuquerque-Xavier, A. C.; Leve, F.; Tanaka, M. N.; Martins de Araujo, W.; Oliveira, S. S.; Benchimol, M.; De Souza, W. Golgi complex disassembly caused by light-activated calphostin C involves MAPK and PKA. Tissue Cell 2007, 39, 161-169. 
Boije af Gennäs G et al. Curr Top Med Chem. 2011; 11(11): 1370-92

The final version of record is available at http://www.eurekaselect.com/88010/article

DOI: $10.2174 / 156802611795589584$

[223] Sciorra, V. A.; Hammond, S. M.; Morris, A. J. Potent direct inhibition of mammalian phospholipase D isoenzymes by calphostin-c. Biochemistry 2001, 40, 2640-2646.

[224] Chiarini, A.; Whitfield, J. F.; Pacchiana, R.; Marconi, M.; Armato, U.; Dal Pra, I. Calphostin $\mathrm{C}$, a remarkable multimodal photodynamic killer of neoplastic cells by selective nuclear lamin B1 destruction and apoptogenesis (Review). Oncol. Rep. 2010, 23, 887-892.

[225] Lown, J. W. 1996 Hoffman-LaRoche Award Lecture Photochemistry and photobiology of perylenequinones. Can. J. Chem. 1997, 75, 99-119.

[226] Wender, P. A.; Kee, J. M.; Warrington, J. M. Practical synthesis of prostratin, DPP, and their analogs, adjuvant leads against latent HIV. Science 2008, 320, 649-652.

[227] Marquez, N.; Calzado, M. A.; Sanchez-Duffhues, G.; Perez, M.; Minassi, A.; Pagani, A.; Appendino, G.; Diaz, L.; Munoz-Fernandez, M. A.; Munoz, E. Differential effects of phorbol-13-monoesters on human immunodeficiency virus reactivation. Biochem. Pharmacol. 2008, 75, 1370-1380.

[228] Gulakowski, R. J.; McMahon, J. B.; Buckheit, R. W.,Jr; Gustafson, K. R.; Boyd, M. R. Antireplicative and anticytopathic activities of prostratin, a non-tumor-promoting phorbol ester, against human immunodeficiency virus (HIV). Antiviral Res. 1997, 33, 87-97.

[229] Hezareh, M.; Moukil, M. A.; Szanto, I.; Pondarzewski, M.; Mouche, S.; Cherix, N.; Brown, S. J.; Carpentier, J. L.; Foti, M. Mechanisms of HIV receptor and co-receptor downregulation by prostratin: role of conventional and novel PKC isoforms. Antivir. Chem. Chemother. 2004, 15, 207-222.

[230] Kulkosky, J.; Culnan, D. M.; Roman, J.; Dornadula, G.; Schnell, M.; Boyd, M. R.; Pomerantz, R. J. Prostratin: activation of latent HIV-1 expression suggests a potential inductive adjuvant therapy for HAART. Blood 2001, 98, 3006-3015. 
Boije af Gennäs G et al. Curr Top Med Chem. 2011; 11(11): 1370-92

The final version of record is available at http://www.eurekaselect.com/88010/article

DOI: $10.2174 / 156802611795589584$

[231] Williams, S. A.; Chen, L. F.; Kwon, H.; Fenard, D.; Bisgrove, D.; Verdin, E.; Greene,

W. C. Prostratin antagonizes HIV latency by activating NF-кB. J. Biol. Chem. 2004, 279, $42008-42017$.

[232] Kato, Y.; Scheuer, P. J. Aplysiatoxin and debromoaplysiatoxin, constituents of the marine mollusk Stylocheilus longicauda (Quoy and Gaimard, 1824). J. Am. Chem. Soc. 1974, 96, 2245-2246.

[233] Fujiki, H.; Suganuma, M.; Nakayasu, M.; Hoshino, H.; Moore, R. E.; Sugimura, T. The third class of new tumor promoters, polyacetates (debromoaplysiatoxin and aplysiatoxin), can differentiate biological actions relevant to tumor promoters. Gann 1982, 73, 495-497.

[234] Horowitz, A. D.; Fujiki, H.; Weinstein, I. B. Comparative effects of aplysiatoxin, debromoaplysiatoxin, and teleocidin on receptor binding and phospholipid metabolism. Cancer Res. 1983, 43, 1529-1535.

[235] Nakagawa, Y.; Yanagita, R. C.; Hamada, N.; Murakami, A.; Takahashi, H.; Saito, N.; Nagai, H.; Irie, K. A simple analogue of tumor-promoting aplysiatoxin is an antineoplastic agent rather than a tumor promoter: development of a synthetically accessible protein kinase C activator with bryostatin-like activity. J. Am. Chem. Soc. 2009, 131, 7573-7579.

[236] Marner, F.; Krick, W.; Gellrich, B.; Jaenicke, L. Irigermanal and Iridogermanal: Two New Triterpenoids from Rhizomes of Iris germanica L. J. Org. Chem. 1982, 47, 2531-2536. [237] Takahashi, K.; Suzuki, S.; Hano, Y.; Nomura, T. Protein kinase C activation by iridal type triterpenoids. Biol. Pharm. Bull. 2002, 25, 432-436.

[238] Shao, L.; Lewin, N. E.; Lorenzo, P. S.; Hu, Z.; Enyedy, I. J.; Garfield, S. H.; Stone, J. C.; Marner, F. J.; Blumberg, P. M.; Wang, S. Iridals are a novel class of ligands for phorbol ester receptors with modest selectivity for the RasGRP receptor subfamily. J. Med. Chem. 2001, 44, 3872-3880. 
Boije af Gennäs G et al. Curr Top Med Chem. 2011; 11(11): 1370-92

The final version of record is available at http://www.eurekaselect.com/88010/article

DOI: $10.2174 / 156802611795589584$

[239] Corbu, A.; Aquino, M.; Pratap, T. V.; Retailleau, P.; Arseniyadis, S. Enantioselective synthesis of iridal, the parent molecule of the iridal triterpenoid class. Org. Lett. 2008, 10, 1787-1790.

[240] Shakibaei, M.; Harikumar, K. B.; Aggarwal, B. B. Resveratrol addiction: to die or not to die. Mol. Nutr. Food Res. 2009, 53, 115-128.

[241] Stewart, J. R.; Ward, N. E.; Ioannides, C. G.; O'Brian, C. A. Resveratrol preferentially inhibits protein kinase C-catalyzed phosphorylation of a cofactor-independent, arginine-rich protein substrate by a novel mechanism. Biochemistry 1999, 38, 13244-13251.

[242] Aggarwal, B. B.; Bhardwaj, A.; Aggarwal, R. S.; Seeram, N. P.; Shishodia, S.; Takada, Y. Role of resveratrol in prevention and therapy of cancer: preclinical and clinical studies. Anticancer Res. 2004, 24, 2783-2840.

[243] Shih, A.; Zhang, S.; Cao, H. J.; Boswell, S.; Wu, Y. H.; Tang, H. Y.; Lennartz, M. R.; Davis, F. B.; Davis, P. J.; Lin, H. Y. Inhibitory effect of epidermal growth factor on resveratrol-induced apoptosis in prostate cancer cells is mediated by protein kinase C- $\alpha$. Mol. Cancer. Ther. 2004, 3, 1355-1364.

[244] Atten, M. J.; Godoy-Romero, E.; Attar, B. M.; Milson, T.; Zopel, M.; Holian, O. Resveratrol regulates cellular PKC $\alpha$ and $\delta$ to inhibit growth and induce apoptosis in gastric cancer cells. Invest. New Drugs 2005, 23, 111-119.

[245] Majhi, A.; Rahman, G. M.; Panchal, S.; Das, J. Binding of curcumin and its long chain derivatives to the activator binding domain of novel protein kinase C. Bioorg. Med. Chem. 2010, 18, 1591-1598.

[246] Yang, F.; Lim, G. P.; Begum, A. N.; Ubeda, O. J.; Simmons, M. R.; Ambegaokar, S. S.; Chen, P. P.; Kayed, R.; Glabe, C. G.; Frautschy, S. A.; Cole, G. M. Curcumin inhibits formation of amyloid $\beta$ oligomers and fibrils, binds plaques, and reduces amyloid in vivo. J. Biol. Chem. 2005, 280, 5892-5901. 
Boije af Gennäs G et al. Curr Top Med Chem. 2011; 11(11): 1370-92

The final version of record is available at http://www.eurekaselect.com/88010/article

DOI: $10.2174 / 156802611795589584$

[247] Begum, A. N.; Jones, M. R.; Lim, G. P.; Morihara, T.; Kim, P.; Heath, D. D.; Rock, C. L.; Pruitt, M. A.; Yang, F.; Hudspeth, B.; Hu, S.; Faull, K. F.; Teter, B.; Cole, G. M.; Frautschy, S. A. Curcumin structure-function, bioavailability, and efficacy in models of neuroinflammation and Alzheimer's disease. J. Pharmacol. Exp. Ther. 2008, 326, 196-208.

[248] Conboy, L.; Foley, A. G.; O'Boyle, N. M.; Lawlor, M.; Gallagher, H. C.; Murphy, K. J.; Regan, C. M. Curcumin-induced degradation of PKC $\delta$ is associated with enhanced dentate NCAM PSA expression and spatial learning in adult and aged Wistar rats. Biochem. Pharmacol. 2009, 77, 1254-1265.

[249] Woo, M. S.; Jung, S. H.; Kim, S. Y.; Hyun, J. W.; Ko, K. H.; Kim, W. K.; Kim, H. S. Curcumin suppresses phorbol ester-induced matrix metalloproteinase- 9 expression by inhibiting the PKC to MAPK signaling pathways in human astroglioma cells. Biochem. Biophys. Res. Commun. 2005, 335, 1017-1025.

[250] Epstein, J.; Sanderson, I. R.; Macdonald, T. T. Curcumin as a therapeutic agent: the evidence from in vitro, animal and human studies. Br. J. Nutr. 2010, 103, 1545-1557.

[251] Boije af Gennäs, G.; Talman, V.; Aitio, O.; Ekokoski, E.; Finel, M.; Tuominen, R. K.; Yli-Kauhaluoma, J. Design, synthesis, and biological activity of isophthalic acid derivatives targeted to the $\mathrm{C} 1$ domain of protein kinase C. J. Med. Chem. 2009, 52, 3969-3981.

[252] Galkin, A.; Surakka, A.; Boije af Gennäs, G.; Ruotsalainen, T.; Kreander, K.; Tammela, P.; Yli-Kauhaluoma, J.; Vuorela, P. Hydrophobic derivatives of 5(hydroxymethyl)isophthalic acid that selectively induce apoptosis in leukemia cells but not in fibroblasts. Drug Dev. Res. 2008, 69, 185-195.

[253] Appendino, G.; Jakupovic, S.; Tron, G. C.; Jakupovic, J.; Milon, V.; Ballero, M. Macrocyclic diterpenoids from Euphorbia semiperfoliata. J. Nat. Prod. 1998, 61, 749-756.

[254] Bedoya, L. M.; Marquez, N.; Martinez, N.; Gutierrez-Eisman, S.; Alvarez, A.; Calzado, M. A.; Rojas, J. M.; Appendino, G.; Munoz, E.; Alcami, J. SJ23B, a jatrophane diterpene 
Boije af Gennäs G et al. Curr Top Med Chem. 2011; 11(11): 1370-92

The final version of record is available at http://www.eurekaselect.com/88010/article

DOI: $10.2174 / 156802611795589584$

activates classical PKCs and displays strong activity against HIV in vitro. Biochem. Pharmacol. 2009, 77, 965-978.

[255] Ghoul, A.; Serova, M.; Astorgues-Xerri, L.; Bieche, I.; Bousquet, G.; Varna, M.; Vidaud, M.; Phillips, E.; Weill, S.; Benhadji, K. A.; Lokiec, F.; Cvitkovic, E.; Faivre, S.; Raymond, E. Epithelial-to-mesenchymal transition and resistance to ingenol 3-angelate, a novel protein kinase C modulator, in colon cancer cells. Cancer Res. 2009, 69, 4260-4269.

[256] Dries, D. R.; Gallegos, L. L.; Newton, A. C. A single residue in the C1 domain sensitizes novel protein kinase $\mathrm{C}$ isoforms to cellular diacylglycerol production. J. Biol. Chem. 2007, 282, 826-830. 